\begin{tabular}{|c|c|}
\hline Title & The effect of moving to a territorial tax system on profit repatriation : evidence from Japan \\
\hline \multicolumn{2}{|l|}{ Sub Title } \\
\hline Author & $\begin{array}{l}\text { 長谷川, 誠(Hasegawa, Makoto) } \\
\text { 清田, 耕造(Kiyota, Kozo) }\end{array}$ \\
\hline Publisher & Keio Economic Observatory Sangyo Kenkyujo \\
\hline Publication year & 2015 \\
\hline Jtitle & KEO discussion paper No.135 (2015. 6) \\
\hline \multicolumn{2}{|l|}{ JaLC DOI } \\
\hline Abstract & $\begin{array}{l}\text { In an increasingly globalized world, the design of international tax systems in terms of taxation } \\
\text { on foreign corporate incomes has received much attention from policymakers and economists } \\
\text { alike. In the past, Japan's worldwide tax system taxed foreign source income upon repatriation. } \\
\text { However, to stimulate dividend repatriations from Japanese-owned foreign affiliates, Japan } \\
\text { introduced a foreign dividend exemption in } 2009 \text { that exempts dividends remitted by Japanese- } \\
\text { owned foreign affiliates to their parent firms from home taxation. This paper examines the effect } \\
\text { of this dividend exemption on profit repatriations by Japanese multinationals. We find that the } \\
\text { response of Japanese-owned affiliates to the dividend exemption was heterogeneous. More } \\
\text { particularly, foreign affiliates with a large stock of retained earnings were generally more } \\
\text { responsive to the reform and significantly increased dividend payments to their parent firms in } \\
\text { response to the enactment of the dividend exemption system. Dividend payments by these } \\
\text { affiliates also became more sensitive to withholding tax rates on dividends levied by host } \\
\text { countries under the new exemption system. }\end{array}$ \\
\hline Notes & 挿表 \\
\hline Genre & Technical Report \\
\hline URL & $\begin{array}{l}\text { https://koara.lib.keio.ac.jp/xoonips/modules/xoonips/detail.php?koara_id=AA10715861-0000013 } \\
\text { 5-0001 }\end{array}$ \\
\hline
\end{tabular}

慶應義塾大学学術情報リポジトリ(KOARA)に掲載されているコンテンツの著作権は、それぞれの著作者、学会または出版社/発行者に帰属し、その権利は著作権法によって 保護されています。引用にあたっては、著作権法を遵守してご利用ください。

The copyrights of content available on the KeiO Associated Repository of Academic resources (KOARA) belong to the respective authors, academic societies, or publishers/issuers, and these rights are protected by the Japanese Copyright Act. When quoting the content, please follow the Japanese copyright act. 
KEO Discussion Paper No. 135

The Effect of Moving to a Territorial Tax System on Profit Repatriation: Evidence from Japan

Makoto Hasegawa

National Graduate Institute for Policy Studies (GRIPS)

Kozo Kiyota

Keio University 


\title{
The Effect of Moving to a Territorial Tax System on Profit Repatriation: Evidence from Japan*
}

\author{
Makoto Hasegawa ${ }^{\dagger}$ Kozo Kiyota ${ }^{\ddagger}$
}

June 2015

\begin{abstract}
In an increasingly globalized world, the design of international tax systems in terms of taxation on foreign corporate incomes has received much attention from policymakers and economists alike. In the past, Japan's worldwide tax system taxed foreign source income upon repatriation. However, to stimulate dividend repatriations from Japanese-owned foreign affiliates, Japan introduced a foreign dividend exemption in 2009 that exempts dividends remitted by Japanese-owned foreign affiliates to their parent firms from home taxation. This paper examines the effect of this dividend exemption on profit repatriations by Japanese multinationals. We find that the response of Japanese-owned affiliates to the dividend exemption was heterogeneous. More particularly, foreign affiliates with a large stock of retained earnings were generally more responsive to the reform and significantly increased dividend payments to their parent firms in response to the enactment of the dividend exemption system. Dividend payments by these affiliates also became more sensitive to withholding tax rates on dividends levied by host countries under the new exemption system.
\end{abstract}

Keywords: International taxation; Worldwide tax system; Territorial tax system; Profit repatriation; Dividend exemption

JEL classification: H25; F23

${ }^{*}$ This paper is part of the research project "Determinants of the Productivity Gap among Firms in Japan," undertaken at the Research Institute of Economy, Trade and Industry (RIETI). Hasegawa is especially grateful to his dissertation committee, Joel Slemrod (Chair), James Hines, Stephen Salant, and Jagadeesh Sivadasan, for their invaluable advice, encouragement, and mentoring. The authors also appreciate the helpful comments and suggestions of David Albouy, Christian Gillitzer, Masaki Hotei, Arjan Lejour, Kevin Markle, Kiyoshi Matsubara, Hisahiro Naito, Tom Neubig, Kazuki Onji, Masanori Orihara, Eiji Tajika, Ryuhei Wakasugi and the participants at the University of Michigan Public Finance Seminar, the 2013 National Tax Association Annual Meeting and the 2014 Annual Congress of the International Institute of Public Finance. Hasegawa gratefully acknowledges the financial support of the Nakajima Foundation, the Nomura Foundation, the University of Michigan, the National Graduate Institute for Policy Studies (GRIPS), and the Japan Society for the Promotion of Science Grant-in-Aid for Young Scientists (B), Grant No. 26780172. Kiyota acknowledges the financial support from the Japan Society for the Promotion of Science (S), Grant No. 26220503 and (B), Grant No. 26285058. The usual disclaimers apply.

${ }^{\dagger}$ National Graduate Institute for Policy Studies (GRIPS). E-mail: m-hasegawa@grips.ac.jp.

${ }^{\ddagger}$ Keio Economic Observatory, Keio University and RIETI. E-mail: kiyota@sanken.keio.ac.jp 


\section{Introduction}

In an increasingly globalized world, the design of international tax policies, in terms of whether and how corporate incomes earned in foreign countries by multinational firms are taxed has received much attention from policymakers and economists alike. While taxing foreign source income would certainly raise revenue, international tax rules significantly influence the business activities of multinational corporations, including the location of foreign direct investment, income reallocation (income shifting) through transfer pricing, and profit repatriation. For instance, the U.S. taxes foreign income upon repatriation, allowing foreign tax credits for corporate income taxes and other related taxes paid to foreign governments under the so-called worldwide income tax system. In contrast to a worldwide income tax system, a territorial tax system exempts foreign income from home taxation, with such systems employed by many developed countries, including Australia, Belgium, Canada, France, Germany, Italy, the Netherlands, and the U.K.. ${ }^{1}$ There is a longstanding debate in the U.S. on the merits of moving from the present worldwide tax system to a territorial tax system.

Japan, the focus of this study, used a worldwide income tax system until the end of March 2009. ${ }^{2}$ At that time, the Japanese government was concerned that under the existing system, Japanese multinational corporations kept a large portion of the profits earned by their foreign affiliates abroad, and did not repatriate them back to Japan. Japanese firms arguably had incentive to do so because foreign incomes were taxed at high rates (as high as 40\%) upon repatriation. ${ }^{3}$ As a means of stimulating dividend repatriation, Japan introduced a foreign dividend exemption system in April 2009 that exempted dividends remitted by foreign affiliates to their Japanese parent firms from home taxation. Thus, with the introduction of the dividend exemption system, the Japanese corporate tax system effectively moved to a territorial tax system. Because this reform drastically changed the way in which the Japanese government taxed the foreign profits of Japanese corporations, the reform would significantly affect the business activities of multinational corporations, including decisions on foreign direct investment, income shifting, and profit repatriation.

This paper examines the effect of moving to a territorial tax system (dividend exemption) on profit repatriation by Japanese multinationals. One compelling motivation is that few studies have empirically examined the actual outcomes of the change in the regime from a

\footnotetext{
${ }^{1}$ As of 2012, 28 of the 34 OECD countries employed territorial tax systems, while only the remaining six countries (the U.S., Chile, Ireland, Israel, South Korea, and Mexico) used worldwide tax systems (PwC, 2013).

${ }^{2}$ In Japan, the fiscal year runs from April 1 to March 31.

${ }^{3}$ In 2009, the corporate income tax rate in Japan was the highest among the OECD member countries (OECD, 2010).
} 
worldwide tax system to a territorial tax system. ${ }^{4}$ Tajika et al. (2014), which is published in Japanese, investigate the impact of Japan's dividend exemption on dividends received by Japanese parent firms from their foreign subsidiaries using parent firm-level data from 2008 to 2009. ${ }^{5}$ They find that more parent firms, especially those facing greater demand for cash, increased dividends received from their foreign affiliates in response to the enactment of the dividend exemption in 2009. However, their analysis does not take into account either the location of foreign affiliates owned by Japanese parent firms or the tax rates of the host countries. Elsewhere, Egger et al. (forthcoming) examine the foreign dividend exemption enacted under a U.K. tax reform in 2009 and find that foreign affiliates owned by U.K. multinational firms responded to the tax reform by increasing dividend payments to their owners. However, there are two limitations regarding their data. First, they are unable to observe dividend payments directly and thus rely on an approximate measure of dividend payments. ${ }^{6}$ Second, because they calculate dividend payments using the balance sheet, they are unable to identify the recipients.

Using unique confidential survey data for Japanese multinational corporations, this paper provides the first evidence concerning the behavioral response of Japanese-owned foreign affiliates to the adoption of a territorial tax system. As detailed later, each foreign affiliate faced a different tax cost as a result of paying dividends to its parent firm in Japan before and after the tax reform, depending on the corporate tax rate and the withholding tax rate on dividends imposed by the host country. In other words, the tax benefit (or cost) from the switch to the territorial tax system depends on the location of the foreign affiliates. The contribution of our study is to identify the differential impacts of the tax reform on dividend repatriations using detailed information on foreign affiliates and the tax rates of the host countries. In addition, the use of affiliate-level panel data from 2006 to 2011 enables us to evaluate the effect of the tax reform over a longer period.

We use the micro database of the annual survey conducted by the Ministry of Economy, Trade and Industry of Japan (METI), the Survey of Overseas Business Activities. This survey provides information on the financial and operating characteristics of Japanese-owned

\footnotetext{
${ }^{4}$ The extant literature utilizes cross-country differences in international tax systems to examine the effect of corporate taxes under the two tax regimes on foreign direct investment (Slemrod, 1990; Hines, 1996; Altshuler and Grubert, 2001; Bénassy-Quéré, Fontagné, and Lahrèche-Révil, 2005). Desai and Hines (2004) estimate a tax burden on foreign income of $\$ 50$ billion per year under the U.S. worldwide income tax system.

${ }^{5}$ Some studies also examine the impact of the Japanese dividend exemption on firm value. Sakurada and Nakanishi (2011) and Bradley et al. (2014) examine investor reactions to news of the dividend exemption during fiscal year 2008 using an event study methodology. However they do not investigate the actual consequences of the transition to the dividend exemption system after the 2009 tax reform.

${ }^{6}$ Dividend payments in 2009 are calculated as the difference between the shareholder funds available for distribution after current profits in 2008 and shareholder funds available for distribution before current profits in 2009.
} 
foreign affiliates, including dividends paid to Japanese investors. Using another METI survey, the Basic Survey of Japanese Business Structure and Activities, containing financial information on parent firms, we construct affiliate-level panel data that includes parent firm information and analyze the period from 2006 to 2011. Unlike Egger et al. (forthcoming), the key advantage of our data is that we can directly observe dividends paid by foreign affiliates to their Japanese parent firms.

We find that the response of Japanese multinationals to the dividend exemption was heterogeneous. Foreign affiliates with a large payout capacity for dividends (the top $10 \%$ of firms in terms of the stock of retained earnings divided by sales in the previous year) were more responsive to the tax reform and significantly increased their dividend payments to their parent firms than other affiliates. Dividend payments by these affiliates also became more responsive to withholding tax rates on dividends because the withholding taxes on dividends were no longer creditable under the new exemption system. We also find that the magnitude of this response increases with the magnitude of the stock of retained earnings.

We also expected that foreign affiliates in low-tax jurisdictions would exhibit a stronger response to the tax reform because the tax costs for dividend repatriation from these affiliates were higher under the worldwide tax system. However, we find no evidence that the change in dividend payments was positively associated with the grossed-up tax rate differential between Japan and other countries.

The rest of the paper is organized as follows. Section 2 describes the background and the provisions for dividend exemption enacted in Japan. Section 3 calculates the tax costs of remitting profits from foreign subsidiaries to their parent firms in Japan through dividends, royalties, or interest, and shows how the dividend exemption changed the tax costs of profit repatriation. Section 4 describes the data, while Section 5 presents the empirical results from a preliminary analysis of the response of Japanese multinationals to the dividend exemption. Section 6 extends the empirical model in Section 5 to analyze the heterogeneous responses to the dividend exemption depending on the magnitude of the stock of retained earnings in the foreign affiliates. Section 7 provides robustness checks of the results in Section 6. Section 8 concludes.

\section{The Dividend Exemption System Enacted in Japan in 2009}

In May 2008, a subcommittee on international taxation at the METI began to discuss the introduction of a dividend exemption in the corporate tax reform slated for 2009. This was 
publicly known because newspaper articles reported this development at the time. ${ }^{7}$ In August 2008, the subcommittee released an interim report and proposed introducing a dividend exemption (METI, 2008a). In the report, the METI estimated that the stock of retained earnings of Japanese-owned foreign affiliates in 2006 was some 17 trillion Japanese yen. ${ }^{8}$ Their concern was that an excessive amount of profit was retained in foreign countries to avoid home-country taxation in Japan, which distorted the decisions of Japanese corporations on the timing of profit repatriation and reduced domestic R\&D investment that could be financed from foreign source income. ${ }^{9}$ As for the expected effects of the dividend exemption, METI (2008a) argued that the dividend exemption system would help to: (1) stimulate dividend repatriation with the removal of the tax burdens on repatriated dividends, (2) increase domestic capital investment and R\&D investment financed by repatriated foreign profits, and (3) reduce tax compliance costs by simplifying the international tax system. ${ }^{10}$

Following the release of the METI's interim report, tax reform plans containing the adoption of a territorial tax regime were sequentially released by the Government Tax Commission, the Liberal Democratic Party (the ruling party in the Japanese House of Representatives), the Ministry of Finance, and the Cabinet from November 2008 to January 2009. Finally, this regime change was included in the legislation for the 2009 tax reform. The legislation passed into law on March 27, 2009 and came into effect on April 1, 2009. ${ }^{11}$

The dividend exemption system that was introduced permits Japanese resident corporations to deduct $95 \%$ of dividends received from foreign affiliates from their taxable income in accounting years commencing on or after April 1, 2009. The remaining (5\%) of dividends are regarded as expenses incurred by parent firms in earning the dividends and are added to the calculation of their taxable incomes in Japan. ${ }^{12}$ In order to qualify for dividend exemp-

\footnotetext{
${ }^{7}$ This discussion of the foreign dividend exemption largely draws on Aoyama (2009) and Masui (2010).

${ }^{8}$ Equating to 146 billion U.S. dollars at the 2006 exchange rate of 1 USD $=116.299$ JPY (UNCTAD, 2012).

${ }^{9}$ The subcommittee also examined the possibility of introducing a one-time dividend exemption similar to the American Jobs Creation Act of 2004, limiting the use of dividends exempted from home taxation. However, the subcommittee concluded that a one-time dividend exemption would only stimulate dividend repatriations during the period under the exemption rule, and would have an aftereffect that would counteract the effect of the dividend exemption. They were also concerned that limiting the use of exempted dividends would distort the managerial decisions and undermine the managerial efficiency of Japanese corporations (METI, 2008a).

${ }^{10}$ To claim foreign tax credits under the worldwide tax system, Japanese multinationals were required to submit numerous evidential documents to prove tax payments by their foreign affiliates and to calculate the amount of foreign tax credits. Therefore, the foreign tax credit system imposed large tax compliance costs on Japanese multinationals. the METI thus expected the dividend exemption to help reduce tax compliance costs by abolishing the foreign tax credits for repatriated dividends (METI, 2008a).

${ }^{11}$ Bradley et al. (2014) provide additional details on the development of the dividend exemption legislation.

${ }^{12}$ The expenses corresponding to $5 \%$ of the repatriated dividends are assumed to be deducted from the taxable incomes of parent firms when they invest in their subsidiaries, and thus would not be exempted upon repatriation under the new exemption system.
} 
tion, a parent firm must have held at least $25 \%$ of the shares of its affiliate for at least six months prior to the dividend declaration date. ${ }^{13}$ While dividend exemption would reduce corporate tax liabilities on repatriated dividends in Japan, foreign tax credits no longer apply to withholding taxes on repatriated dividends imposed by host countries. The new system is still quite distant from purely source-based taxation. As the term "dividend" exemption suggests, it only exempts foreign income in the form of paid dividends, and does not apply to other types of foreign source income, including royalties, interest payments, income earned by foreign branches, and capital gains. Japanese multinationals can continue to claim foreign tax credits for foreign taxes paid on these incomes.

Finally, because this tax reform concerns a foreign dividend exemption, the difference between Japan's dividend exemption enacted under the 2009 tax reform and the dividend tax deduction enacted in the U.S. under the American Jobs Creation Act of 2004 (AJCA) is also noteworthy. ${ }^{14}$ First, while the AJCA provides U.S. multinational corporations with a special one-time deduction of $85 \%$ of dividends received from their foreign affiliates, Japan's dividend exemption is permanent. Second, under the AJCA, the $85 \%$ exemption applies only to "extraordinary dividends," which are defined as dividend payments exceeding average repatriations over a five-year period ending before July 1, 2003, after excluding the years with the highest and lowest repatriations. ${ }^{15}$ Therefore, the exemption is limited to only part of the dividends paid (extraordinary dividends), and U.S. multinationals could claim dividend tax reductions only if they received foreign dividends that exceeded the average. On the other hand, Japan's dividend exemption applies to $95 \%$ of all dividends as long as the conditions described above are satisfied. ${ }^{16}$ Thus, we note that the exemption permitted under the new tax system in Japan is quite different from and arguably much more generous than the dividend tax reduction implemented under the AJCA in the U.S..

\footnotetext{
${ }^{13}$ The $25 \%$ minimum shareholding requirement is reduced under bilateral tax treaties with several countries. For example, the minimum shareholding is set at $10 \%$ for foreign affiliates in the U.S., Brazil, Australia, and Kazakhstan, and at 15\% for those in France (Aoyama, 2009).

${ }^{14}$ Several studies investigate the effects of the one-time dividend deductions permitted by the American Jobs Creation Act of 2004 on the profit repatriations, domestic investment and employment, market values, and income shifting behavior of U.S. multinational corporations (Oler et al., 2007; Blouin and Krull, 2009; Redmiles, 2009; Bradley, 2011; Dharmapala et al., 2011).

${ }^{15}$ In addition, to be eligible for the dividends-received deduction, dividends must be paid in cash and invested in approved activities in the U.S., although this requirement may not be binding for U.S. multinationals (Blouin and Krull, 2009; Dharmapala et al., 2011).

${ }^{16}$ METI (2008b) estimates that given the requirements described above, more than $95 \%$ of foreign affiliates would be eligible for dividend exemption.
} 


\section{How Dividend Exemption Affects the Profit Repa- triation of Japanese Multinationals}

Hartman (1985) demonstrated that under certain conditions, repatriation taxes do not affect the decisions on marginal investment and dividend payments made by "mature" subsidiaries financing their marginal investment out of their own retained earnings. However, this result depends on the assumption that repatriation tax rates are constant over time. This assumption may not hold because, as we show below, the repatriation tax rates on dividends may change depending on the foreign tax credit positions of the parent firms under a worldwide income tax system and the definition of taxable income (tax bases) in the host countries, and also when the corporate tax rate of a home country changes. ${ }^{17}$ In addition, repatriation tax rates also vary because of changes in the international tax regime, as was the case for Japan in 2009.

In what follows, we calculate the tax costs of remitting profits from foreign subsidiaries to their parent firms in Japan through dividends, royalties, or interest given their decisions on foreign direct investment, and show how the dividend exemption has changed the tax costs of profit repatriation. We then make predictions for our empirical analysis based on these changes in repatriation tax costs.

To consider the tax liabilities on foreign dividends under Japan's worldwide tax system (i.e. that before April 2009) and the new exemption system (i.e. that after April 2009), we calculate the tax costs of remitting an additional dollar of foreign income to Japan through dividends, royalties, or interest. Let $Y_{i j c t}$ denote the pretax profit of affiliate $i$ operating in country $c$ owned by parent $j$ in year $t$ and $T_{i j c t}$ denote the foreign corporate income tax paid by affiliate $i$. We define the average affiliate tax rate as $\hat{\tau}_{i j c t}=T_{i j c t} / Y_{i j c t}$ and denote the statutory corporate tax rates of Japan and country $c$ in year $t$ by $\tau_{H t}$ and $\tau_{c t}$, respectively. We denote withholding tax rates on dividends, royalties, and interest payments in country $c$ and year $t$ by $w_{c t}^{D}, w_{c t}^{R}$, and $w_{c t}^{I}$, respectively.

Under the worldwide tax system operating in Japan prior to April 2009, the tax liability of parent $j$ to receive one dollar of additional dividends from its affiliate $i$ in country $c$ depends on the excess foreign tax credit position of parent $j$ : that is, whether the parent is in the situation of an excess limit or an excess credit. A parent firm whose foreign tax payments are less than the foreign tax credit limit, where the foreign tax credit limit is calculated as the total foreign taxable income multiplied by the Japanese corporate tax rate,

\footnotetext{
${ }^{17}$ There is evidence that repatriation taxes discourage dividend payouts by U.S. corporations (Hines and Hubbard, 1990; Grubert, 1998; Desai et al., 2001). In contrast, using Japanese affiliate-level data, Tajika and Nakamura (2008) find no evidence of the significant effect of corporate taxes on dividend repatriation by Japanese multinationals.
} 
is referred to as being in excess limit. In contrast, if the foreign tax payments are greater than the foreign tax credit limit, the parent is referred to as being in excess credit, and can then use excess foreign tax credits (the difference between the foreign tax payments and the foreign tax credit limit) to reduce its Japanese tax obligations on foreign source income over the following three years.

Suppose parent firm $j$ is in excess limit. It could then claim foreign tax credits for the taxes paid to host country $c$ when affiliate $i$ remits one additional dollar of dividends. The dollar of dividends would be deemed as $1 /\left(1-\hat{\tau}_{i j c t}\right)$ dollars of taxable income in Japan (the gross-up formula), which yields the corporate tax liability of $\tau_{H} /\left(1-\hat{\tau}_{i j c t}\right)$. Parent $j$ also has to pay withholding taxes on the dividend $w_{c t}^{D}$ to country $c$. Thus, the total tax payment to receive one additional dollar of dividends is $\left[\tau_{H t} /\left(1-\hat{\tau}_{i j c t}\right)+w_{c t}^{D}\right]$. Parent $j$ can also claim foreign tax credits for the taxes paid to country $c$, which include the corporate tax payment $\hat{\tau}_{i j c t} /\left(1-\hat{\tau}_{i j c t}\right)$ and the withholding tax on the dollar of dividends $w_{c t}^{D}$. Therefore, the net tax payment of parent $j$ to receive one dollar of dividends from its affiliate $i$ in country $c$ in year $t$ can be written as $P_{i j c t}$ such that

$$
P_{i j c t} \equiv\left[\frac{\tau_{H t}}{1-\hat{\tau}_{i j c t}}+w_{c t}^{D}\right]-\left[\frac{\hat{\tau}_{i j c t}}{1-\hat{\tau}_{i j c t}}+w_{c t}^{D}\right]=\frac{\tau_{H t}-\hat{\tau}_{i j c t}}{1-\hat{\tau}_{i j c t}},
$$

which is the difference between the Japanese statutory tax rate and the subsidiary average tax rate grossed up by the subsidiary average tax rate.

If parent $j$ is in a position of excess credit, the parent can use the excess foreign tax credits to remove its Japanese corporate tax liability. ${ }^{18}$ Then, the net tax payment is $w_{c t}^{D}$. In sum, the tax costs of remitting one dollar of dividends can be written as

$$
\left\{\begin{array}{cl}
P_{i j c t}=\left(\tau_{H t}-\hat{\tau}_{i j c t}\right) /\left(1-\hat{\tau}_{i j c t}\right) & \text { if parent } j \text { is in excess limit; } \\
w_{c t}^{D} & \text { if parent } j \text { is in excess credit. }
\end{array}\right.
$$

Following the introduction of the dividend exemption system (after April 2009), parent $j$ can exclude $95 \%$ of the dividends from its taxable income, and thus only has to include $5 \%$ of the dividends in its taxable income. On the other hand, the parent firm must incur withholding tax on the dollar of dividends, $w_{c t}^{D}$. Thus, the net tax payment to receive the dollar of dividends from affiliate $i$, or the repatriation tax rate under the new exemption system, is

$$
0.05 \tau_{H t}+w_{c t}^{D}
$$

\footnotetext{
${ }^{18}$ Even when parent $j$ is in an excess credit position, the foreign tax credit that parent $j$ can claim is limited up to the Japanese tax liability on the dollar of dividends $\left(\tau_{H t} /\left(1-\hat{\tau}_{i j c t}\right)\right)$.
} 
Therefore, if parent $j$ is in an excess limit position under the worldwide tax system, the dividend exemption system eliminates almost all its corporate tax liability in Japan (except for the withholding tax payment). ${ }^{19}$ The repatriation tax cost of repatriating dividends decreases from $\left(\tau_{H t}-\hat{\tau}_{i j c t}\right) /\left(1-\hat{\tau}_{i j c t}\right)$ to $0.05 \tau_{H t}$ when controlling for the withholding tax rate on dividends $w_{c t}^{D}{ }^{20}$ On the other hand, because withholding taxes on dividends are no longer creditable under the dividend exemption system, parent $i$ has to pay $w_{c t}^{D}$, which would have been creditable under the worldwide tax system before 2009.

When the repatriation tax costs decrease to $0.05 \tau_{H t}$ (controlling for $w_{c t}^{D}$ ), which is the same for all firms, foreign affiliates would increase dividend payments under the new exemption system as long as the repatriation taxes are a binding constraint on their dividend payout decisions. In addition, Japanese multinationals face different repatriation tax costs depending on their foreign tax credit positions and the corporate tax policies of the host countries. Because dividend exemption eliminates Japanese corporate tax liability on repatriated dividends $\left(P_{i j c t}\right)$, dividend payments should become less sensitive to (i.e. less affected by) the difference between the Japanese statutory tax rate and the average tax rate of the subsidiary grossed up by the subsidiary average tax rate $\left(P_{i j c t}\right)$ after 2009 . In other words, under the exemption system, foreign affiliates in lower-tax countries (higher $P_{i j c t}$ ) should pay more dividends than before the tax reform. As we detail later, to control for firm size and the appreciation of the Japanese yen, we measure dividend payments as the share of affiliate sales in our regression analysis. We then expect the following effects of dividend exemption on dividend payment scaled by affiliate sales to Japanese investors:

H1: Dividend repatriations from foreign affiliates increase when controlling for withholding tax rates on dividends.

H2: Dividend payments become less sensitive to the tax rate differentials between Japan and foreign countries $\left(P_{i j c t}\right) .^{21}$

H3: Dividend payments become more sensitive to withholding tax rates on dividends levied by host countries.

\footnotetext{
${ }^{19}$ Because of the relatively high corporate tax rate in Japan, it was highly likely that the foreign tax liability on a dollar of dividends was lower than the tax liability in Japan $\left(\frac{\hat{\tau}_{i j c t}}{1-\hat{\tau}_{i j c t}}+w_{c t}^{D} \leq \frac{\tau_{H t}}{1-\hat{\tau}_{i j c t}}\right)$. In fact, using the data from 2007 to 2011, we find that this holds for $87.9 \%$ of all foreign affiliates. Thus, it is reasonable to assume that most parent firms were in excess limit situations or that even if they were in excess credit, they did not have substantial excess foreign tax credits.

${ }^{20}$ In this section, we assume $P_{i j c t}=\left(\tau_{H t}-\hat{\tau}_{i j c t}\right) /\left(1-\hat{\tau}_{i j c t}\right)>0.05 \tau_{H t}$. In the data from 2007 to 2011, $90.4 \%$ of foreign affiliates satisfy this condition.

${ }^{21}$ In other words, foreign affiliates in lower-tax countries (higher $P_{i j c t}$ ) should increase dividends as scaled by sales more than other affiliates after 2009 .
} 
While the dividend exemption system substantially changes the tax costs of repatriating foreign dividends, it does not change the tax treatment of repatriated royalties and interest payments at all. Consider the tax costs of remitting one additional dollar of a royalty or interest from affiliate $i$ to its parent $j$. Because they are deductible payments, remitting a dollar as a royalty or interest will reduce the corporate tax payment in country $c$ by $\tau_{c t}$. The corporate tax liability on the dollar of deductible payments is $\tau_{H t}$. Parent $j$ also has to remit to the government of country $c$ the withholding tax on one dollar of a royalty $w_{c t}^{R}$ or on a dollar of interest $w_{c t}^{I}$. The total tax payment for the dollar of royalty is $\left[\left(\tau_{H t}-\tau_{c t}\right)+w_{c t}^{R}\right]$ while that for the dollar of interest is $\left[\left(\tau_{H t}-\tau_{c t}\right)+w_{c t}^{I}\right]$.

If parent $j$ is in excess limit, it would claim a foreign tax credit for the withholding tax on the dollar of royalty or interest, $\left(w_{c t}^{R}\right.$ or $\left.w_{c t}^{I}\right)$. The net tax payment of remitting one dollar of deductible payments is $\left(\tau_{H t}-\tau_{c t}\right)$. If parent $j$ is in an excess credit position, excess foreign tax credits would reduce the tax liability in Japan by up to $\tau_{H t}$, and the net tax costs would be $\left(w_{c t}^{R}-\tau_{c t}\right)$ for the royalty payment and $\left(w_{c t}^{I}-\tau_{c t}\right)$ for the interest payment.

In summary, regardless of the introduction of the dividend exemption system, the net tax costs of remitting one additional dollar of a royalty can be written as

$$
\begin{cases}\tau_{H t}-\tau_{c t} & \text { if parent } j \text { is in excess limit; } \\ w_{c t}^{R}-\tau_{c t} & \text { if parent } j \text { is in excess credit. }\end{cases}
$$

The net tax costs of remitting one additional dollar of interest payments can be written as

$$
\begin{cases}\tau_{H t}-\tau_{c t} & \text { if parent } j \text { is in excess limit; } \\ w_{c t}^{I}-\tau_{c t} & \text { if parent } j \text { is in excess credit. }\end{cases}
$$

As Grubert (1998) shows, those tax costs could affect dividend repatriations to the extent that royalties and interest payments substitute or complement dividends as an alternative means of profit repatriation. In the following sections, we empirically examine how the response of dividend payments by Japanese-owned foreign affiliates to the repatriation tax costs changed because of the introduction of the dividend exemption regime and test hypotheses H1-H3.

\section{Data}

We use the micro database of the annual survey conducted by the METI, the Survey of Overseas Business Activities. The main purpose of this survey is to obtain basic information on the business activities of the foreign subsidiaries of Japanese firms. The survey covers all 
Japanese firms (except those in the finance, insurance, and real estate industries) that owned affiliates abroad as at the end of the fiscal year (March 31). A foreign affiliate of a Japanese firm is defined as a firm that is located in a foreign country and of which the Japanese firm owns directly or indirectly at least a $10 \%$ equity share, covering up to second-tier subsidiaries. The survey provides data on the financial and operating characteristics of Japanese firms operating abroad, including dividends and royalties paid to Japanese investors. ${ }^{22}$

To control for parent firm characteristics, we use another METI survey, the Basic Survey of Japanese Business Structure and Activities. This survey covers all firms with 50 or more employees and capital or investment funds of at least 30 million yen, for both manufacturing and non-manufacturing industries. The survey provides data on the financial and operating characteristics of Japanese parent firms.

We merge these two annual cross-sectional surveys to develop a longitudinal (panel) data set for foreign subsidiaries from 2006 to 2011. Each subsidiary is traced throughout the period using the parent and affiliate IDs as a key. ${ }^{23}$ The merged panel data from the METI surveys contains 50,667 observations for foreign affiliates in the sample from 2007 to 2011 with information on dividend payments available, while another 22,124 observations between 2007 and 2011 have missing values for dividend payments, and thus are not available for our analysis. $^{24}$

Table 1 provides summary statistics of the dividend payments by foreign affiliates in millions of yen for each year from 2007 to 2011. Notably, both the sum and mean of dividend payments in 2009, the first year of the dividend exemption system, are larger than in 2007 and 2008. The total amount of dividend payments decreased by $16 \%$ from 2007 to 2008 and increased by $43.6 \%$ from 2008 to 2009 . There is a similar trend in the mean of dividend payments. However, it is worth noting that the increase in the total amount of dividends in 2009 results from a relatively small number of foreign affiliates. Although the sum and mean of dividends are larger in 2009 than in 2007 and 2008, the dividend payments at the 75th, 90th, and 95th percentiles in 2009 are smaller than those in 2007 and 2008. This implies

\footnotetext{
${ }^{22}$ There are many missing values for the dividend information because the respondents (parent firms) left the question on dividends blank when no dividends were paid. We also found that the number of observations with missing values for dividends increased from 2010, while the number of observations with zero dividends decreased to almost the same extent. We speculate that zero dividends were recorded as missing values for these affiliates in 2010 and 2011. We replaced missing values for dividends in 2010 or 2011 or in both years by zero only if an affiliate reported dividend payments in all of the years before 2009 when the affiliate appeared in the sample.

${ }^{23}$ The parent ID is from the Basic Survey of Japanese Business Structure and Activities. We also used the information on location and establishment year to trace each subsidiary.

${ }^{24}$ Before 2007, the METI survey collected dividend payments to Japanese investors every four years, and thus the information on dividends is unavailable for 2006 . We collect the survey information for 2006 to use the lagged values of retained earnings of foreign affiliates and pretax profit, total assets, and total debt of the parent firms in our regression analysis.
} 
that dividend payments above the 99th percentile in 2009 were much larger than those in 2007 and 2008. As a result, the total dividend payments and the mean of the dividends paid by affiliates are larger in 2009 than the previous two years. ${ }^{25}$ The mean of dividends in 2011 is higher than under the worldwide tax system in 2007 and 2008, while that in 2010 is the lowest among the five years in the sample. We also note the dividend payment distribution is heavily skewed to the left, signifying that most foreign affiliates paid no dividends (as detailed in Table 3).

$$
==\text { Table } 1==
$$

There is a caveat when we look at dividend payments measured in Japanese yen. The Japanese yen consistently appreciated over the entire data period. Thus, without normalization, the increase in dividend repatriation could be undervalued, as measured by Japanese yen. $^{26}$ Table 2 provides summary statistics of the dividend payments by foreign affiliates scaled by sales to control for the size of the affiliates and for the changes in the foreign exchange rates. In 2008, the mean value of the dividend payments as a share of sales is lowest (0.0241), possibly because of the financial crisis triggered by the bankruptcy of Lehman Brothers, which severely affected the Japanese economy in 2008. Except for 2008, the mean of the dividend payments as a share of sales remains between 0.040 and 0.048 and does not show a clear increase after the tax reform compared with that in 2007. However, we note that dividend payments scaled by sales are larger for each year after 2009 than before 2008 at the 90th percentile and above. Table 3 details the number of foreign affiliates that paid no dividends, the number of affiliates paying dividends to Japanese investors, and the proportion of affiliates paying dividends in each year from 2007 to 2011. Strikingly, the proportion of foreign affiliates paying dividends is lowest in 2009 (25.9\%), is relatively stable over time between $25.9 \%$ and $30.2 \%$, and does not clearly increase after the tax reform in 2009 .

$$
===\text { Tables } 2 \text { and } 3==
$$

In summary, while dividend payments scaled by sales at the 90th percentile and above increased after 2009, the proportion of foreign affiliates paying dividends did not increase. This is suggestive of the heterogeneous response of Japanese multinationals to dividend exemption. Although the dividend exemption system may not stimulate dividend repatriations from most foreign affiliates that had not paid dividends under the worldwide tax system, a

\footnotetext{
${ }^{25}$ To maintain confidentiality, we are unable to provide the maximum and minimum values.

${ }^{26}$ The exchange rates between U.S. dollars and Japanese yen during the data collection period are as follows: $1 \mathrm{USD}=117.8 \mathrm{JPY}$ in 2007, 103.4 JPY in 2008, 93.6 JPY in 2009, 87.8 JPY in 2010, and 79.8 JPY in 2011 (UNCTAD, 2012)
} 
small portion of firms that had paid large amounts of dividends under the worldwide tax system may increase dividends further as a result of dividend exemption. These observations motivate our regression analysis in the following sections by taking into account the possibility that the response of foreign affiliates to dividend exemption varies depending on the payout capacity for dividends, as measured by the stock of retained earnings.

Finally, Tables A1, A2, and A3 provide the number of foreign affiliates, the total amount of dividends paid by these affiliates to Japanese investors, and the mean of the affiliate average tax rates for each country in each year, respectively. ${ }^{27}$ We note that the locations of Japanese-owned foreign affiliates favor the U.S., China, and other Asian countries, including Thailand, Hong Kong, Singapore, Taiwan, Malaysia, South Korea, and Indonesia.

\section{Preliminary Analysis: Before-and-After Comparison}

To test hypotheses $\mathrm{H} 1-\mathrm{H} 3$, we examine how the dividend exemption system affected the repatriation behavior of Japanese multinational corporations and changed the responsiveness of repatriated dividends to repatriation taxes (corporate taxes and withholding taxes) after 2009. ${ }^{28}$ As a preliminary analysis of dividend repatriation patterns before and after the tax reform, our identification strategy in this section employs a version of a before-and-after comparison using a post-reform dummy variable (set equal to one only if $t \geq 2009$ and zero otherwise) in our regression analysis described below. ${ }^{29}$

We attempt to capture the causal effects of the dividend exemption with the post-reform dummy variable and its interaction terms while controlling for confounding factors that potentially affect dividend payments (measured in Japanese yen), such as macroeconomic conditions, foreign exchange rates, the tax policies of the host countries, and parent firm characteristics, as follows. First, we scale dividend payments by affiliate sales to control for affiliate size and for the purpose of normalization robust to the appreciation of the Japanese yen. Second, we include country and industry fixed effects to control for systematic differences in dividend payments across different industries and countries, which are possibly because of different industry-specific and country-specific economic conditions over the entire

\footnotetext{
${ }^{27}$ In these tables, we focus on the 41 countries where there are at least 50 observations in total from 2006 to 2011 .

${ }^{28}$ One limitation in our data set is that it does not include information on the foreign tax credit position of the parent firms (i.e. excess limit or excess credit). Thus, we cannot identify the tax costs of remitting dividends for each affiliate based on its parent's credit position. However, as Grubert (1998) and Desai et al. (2001) point out, because companies are uncertain about their long-run credit positions and foreign tax credit positions are endogenous with respect to repatriation behavior, adjusting the repatriation tax costs depending on the parent's foreign tax credit position would also be problematic.

${ }^{29}$ Blouin et al. (2004) and Chetty and Saez (2005) employ a before-and-after comparison approach to examine the effects of the 2003 dividend tax cut in the U.S. on dividend payments to individual investors.
} 
data period. We also include a set of year dummies whenever possible. Third, we include foreign exchange rates between Japanese yen and the local currencies and real GDP growth rates of the host countries to control for exchange gains upon repatriation and reinvestment opportunities, respectively. Finally, to reflect the demand for internal cash by parent firms, we control for the profitability and total debt of the parent firms.

We estimate the following equation in the spirit of Grubert (1998):

$$
\begin{aligned}
(\text { Dividend/Sales })_{i j c t}= & \alpha_{0}+\alpha_{1} P_{i j c t}+\alpha_{2} w_{c t}^{D}+\alpha_{3} w_{c t}^{R}+\alpha_{4} w_{c t}^{I}+\alpha_{5} \tau_{c t} \\
& +\beta_{0} D E_{t}+\beta_{1}\left(D E_{t} * P_{i j c t}\right)+\beta_{2}\left(D E_{t} * w_{c t}^{D}\right)+\beta_{3}\left(D E_{t} * w_{c t}^{R}\right) \\
& +\beta_{4}\left(D E_{t} * w_{c t}^{I}\right)+\beta_{5}\left(D E_{t} * \tau_{c t}\right)+\gamma X_{i j c t}+\mu_{c}+\nu_{i j}+u_{i j c t},
\end{aligned}
$$

where (Dividend/Sales) ${ }_{i j c t}$ is the dividend payments of affiliate $i$ located in country $c$ to its Japanese parent $j$ divided by affiliate sales, in year $t$. The dummy variable $D E_{t}$ is equal to one if $t \geq 2009$, and zero otherwise. As defined in the previous section, $P_{i j c t}$ is the grossed-up tax rate differential between Japan and country $c{ }^{30}$ The withholding tax rates of country $c$ in year $t$ on dividends, royalties, and interest payments are $w_{c t}^{D}, w_{c t}^{R}$, and $w_{c t}^{I}$, respectively. ${ }^{31}$ The statutory tax rate of country $c$ in year $t$ is $\tau_{c t}{ }^{32}$ The post-reform year dummy $D E_{t}$ and the interaction terms of $D E_{t}$ with these tax variables are intended to capture the changes in dividends paid and the responsiveness of dividends to the tax variables, respectively.

The vectors of other control variables are denoted as $X_{i j c t}$, including the nominal exchange rate between Japanese yen and the local currency in country $c$ normalized to one at the 2005 level, annual real GDP growth rates, lagged parent net profit scaled by total assets, lagged parent total debt scaled by total assets, year dummies, and industry dummies for two-digit industry codes. Country dummies are included and denoted as $\mu_{c}$. Affiliate fixed effects are denoted as $\nu_{i j}$ and included in some specifications. To mitigate the influence of outliers, we winsorize all the firm-level variables used in the analysis at the top and bottom $1 \%$. Tables

\footnotetext{
${ }^{30}$ To bound the average affiliate tax rates $\left(\hat{\tau}_{i j c t}=T_{i j c t} / Y_{i j c t}\right)$ between 0 and 1 and apply the gross-up calculation to $P_{i j c t}=\left(\tau_{H t}-\hat{\tau}_{i j c t}\right) /\left(1-\hat{\tau}_{i j c t}\right)$ appropriately, we dropped observations with negative corporate tax payments $\left(T_{i j c t}<0\right)$ and those with non-positive pretax profits but positive tax payments $\left(Y_{i j c t} \leq 0\right.$ and $\left.T_{i j c t}>0\right)$. The average affiliate tax rate is set to 0 if $T_{i j c t}=0$ and $Y_{i j c t} \leq 0$ to bound the average tax rate from zero. Foreign tax credits applied to up to $50 \%$ (35\% from 2011) of foreign taxable income under Japanese tax law. To consider this provision, and also to mitigate the influence of extreme average tax rates, we replace $\hat{\tau}_{i j c t}=T_{i j c t} / Y_{i j c t}$ with 0.5 if $\hat{\tau}_{i j c t}=T_{i j c t} / Y_{i j c t}>0.5$ when calculating $P_{i j c t}$.

${ }^{31}$ We collect information on withholding tax rates on dividends, royalties, and interest from Ernst \& Young Worldwide Tax Summaries (2006-2011), the documents released by Japan's National Tax Agency that summarize the revisions of tax treaties between Japan and its partner countries ("Summary of the Revision of Withholding Tax Rates"), PricewaterhouseCoopers Worldwide Tax Summaries, and also the database of the Japan External Trade Organization (JETRO), J-FILE (http://www.jetro.go.jp/world/search/cost/).

${ }^{32}$ We obtain data on statutory corporate income tax rates from the KPMG Corporate and Indirect Tax Survey 2011. The statutory tax rates include sub-central (statutory) corporate income tax rates.
} 
4 and 5 provide the definitions and the summary statistics, respectively, for all of these variables after the winsorization.

\section{$===$ Tables 4 and $5==$}

From the hypotheses proposed in the previous section, we expect the signs of the key parameters to be as follows. If the dividend exemption system uniformly stimulated dividend repatriations by foreign affiliates of Japanese multinational firms, the coefficients on $D E_{t}$ should be positive $\left(\beta_{0}>0\right)$, as hypothesized in $\mathrm{H} 1$. The coefficient on $P_{i j c t}$ is expected to be negative $\left(\alpha_{1}<0\right)$ because higher repatriation tax costs would discourage dividend payments under the worldwide tax system. If dividend payments became less sensitive to the tax rate differential between Japan and foreign countries under the new exemption system as hypothesized in $\mathrm{H} 2$, the estimated coefficient on $\left(D E_{t} * P_{i j c t}\right)$ would be positive $\left(\beta_{1}>0\right)$. Another interpretation of $\mathrm{H} 2$ is that if dividend repatriations from lower-tax countries (high $\left.P_{i j c t}\right)$ were discouraged under the worldwide tax system $\left(\alpha_{1}<0\right)$, foreign affiliates in these countries should increase dividends (as scaled by sales) more than other affiliates when dividend exemption substantially eliminates the repatriation tax burden.

We expect the coefficient on $w_{c t}^{D}$ to be insignificant or possibly negative $\left(\alpha_{2}<0\right)$ because the tax price of dividends does not depend on $\left(w_{c t}^{D}\right)$ if a parent firm is in excess limit, which would be the case for most Japanese multinationals, while the tax price equals the withholding tax rate on dividends $\left(w_{c t}^{D}\right)$ if a parent firm is in excess credit. If Japanese corporations care more about the tax costs of withholding taxes on dividends under the new exemption system and thus their dividend repatriations becomes more sensitive to the withholding tax rates on dividends, as hypothesized in H3, the estimated coefficient on $\left(D E_{t} * w_{c t}^{D}\right)$ would be negative $\left(\beta_{2}<0\right)$. The signs of the coefficients on the withholding tax rates on royalties and interest, and the statutory tax rates will depend on how strongly dividends substitute for royalties or interest as alternative means of profit repatriation.

As for the estimation methods, we follow the previous literature (Grubert, 1998; Deasi et al., 2001; Tajika and Nakatani, 2008) and estimate the equations using either a Tobit or ordinary least squares (OLS) procedure. We employ a Tobit procedure because many affiliates ( $72 \%$ of all affiliates in the sample) pay zero dividends, and thus the dependent variable in equation (5) can be considered as a left-censored variable. In the Tobit estimation, we include country and industry fixed effects to control for systematic differences in dividend payments across industries and countries, and hence use across-affiliate variations to identify the parameters. ${ }^{33}$ We also estimate the equation using fixed-effects OLS. The fixed-effects

\footnotetext{
${ }^{33}$ We do not include affiliate fixed effects in the Tobit models because of the incidental parameters problem, which renders estimators in nonlinear panel data models with fixed effects inconsistent and biased. This would be an especially serious problem in a short panel like ours (Greene, 2007).
} 
OLS estimation uses within-affiliate variations to identify the parameters controlling for the time-invariant characteristics of each affiliate.

Table 6 presents the estimation results. Columns 1 and 2 report the coefficients estimated by a Tobit procedure. The point estimates are marginal effects on the latent dependent variable, which can be interpreted as the "desired" amount of dividend payments. ${ }^{34}$ Columns 3 and 4 report the results from the fixed-effects OLS specifications. ${ }^{35}$ The estimated coefficient on $D E_{t}$ is positive in all specifications and significant at the $5 \%$ and $10 \%$ levels in columns 3 and 4, respectively. The OLS estimates imply that, holding affiliate sales fixed, dividend payments are higher than the level in 2007 by $0.5 \%$ of affiliate sales after 2009 . This result is mildly consistent with hypothesis $\mathrm{H} 1 .^{36}$

$$
==\text { Table } 6==
$$

The estimated coefficient on the tax price of dividends $\left(P_{i j c t}\right)$ is negative and statistically different from zero at the $1 \%$ level in the Tobit models, while it is not estimated precisely in the OLS fixed-effects model possibly because of the lack of variations in $P_{i j c t}$ within affiliates over time. This suggests that the Japanese worldwide tax system significantly discouraged dividend repatriation from foreign affiliates in low-tax countries because it would trigger an additional tax liability proportional to the difference between the Japanese and foreign tax rates under the worldwide tax system. However, the estimated coefficient on $\left(D E_{t} * P_{i j c t}\right)$ is negative in all specifications, though mostly insignificant. This is inconsistent with hypothesis $\mathrm{H} 2$, and suggests that dividend payments did not become less sensitive to the tax rate differential between Japan and foreign countries following the enactment of the dividend exemption system. In other words, foreign affiliates in lower-tax countries did not increase dividend payments to their parents significantly more than other affiliates. The coefficient on $\left(D E_{t} * w_{c t}^{D}\right)$ is estimated to be negative in all specifications and significant at the $1 \%$ or $5 \%$ level in the fixed-effects OLS specifications. This is consistent with hypothesis H3, but may not be strongly convincing because the Tobit results do not support the hypothesis.

\footnotetext{
${ }^{34}$ In our analysis, the key parameters of interest are the interaction terms for $D E_{t}$ and the other tax variables. As Ai and Norton (2003) show, the interaction effect on a dependent variable in nonlinear models differs from the marginal effect of the interaction term. Therefore, in the estimation of our empirical models using the Tobit procedure, the marginal effect of the interaction terms on the observed dividend payments (conditional on positive dividend payments) cannot be calculated in the usual manner. Thus, we focus on the marginal effects on the latent variable for dividend payments, which is a linear function of the independent variables.

${ }^{35}$ In the fixed-effects specifications, we do not include either the industry or country dummies because they are almost completely absorbed by the affiliate fixed effects. Nonetheless, we have confirmed that the inclusion of industry and country dummies in the fixed-effects OLS model does not affect our results.

${ }^{36}$ We obtain similar results when we include the post-reform year dummies (2009-2011) separately instead of $D E_{t}$. The estimated coefficients on the post-reform year dummies are positive in all specifications and significant in the fixed-effects OLS specifications.
} 
In summary, from the preliminary analysis we obtain some evidence that foreign affiliates increased dividend payments when scaled by sales and that the repatriation of dividends became more sensitive to withholding tax rates on dividends following the adoption of the territorial tax system. However, we find no evidence that dividend payments became less sensitive to the tax rate differential between Japan and the foreign countries. In other words, there was no strong response from foreign affiliates in low-tax countries. There are some caveats for interpreting these estimation results. First, relying on the post-reform year dummy variables to measure the average change in the level of dividend payments might falsely capture cyclical and sectoral macroeconomic effects after 2009 on profit repatriations (in spite of our attempt to control for those confounding factors with the various control variables). Second, as Tables 1 and 2 imply, the response of foreign affiliates to dividend exemption may be heterogeneous. Foreign affiliates that have a larger dividend payout capacity than other affiliates, for example, those with a larger stock of retained earnings, may have responded more flexibly to the dividend exemption system by increasing dividend payments to their parent firms or changing their dividend payouts depending on the foreign corporate tax rates and the dividend withholding tax rates of the host countries.

\section{Heterogeneous Response to Dividend Exemption: By Stock of Retained Earnings}

As discussed in Section 2, one of the main goals of dividend exemption is to stimulate dividend repatriations from foreign affiliates that had retained and accumulated large foreign profits to avoid home taxation in Japan. It would be worthwhile to consider how these affiliates responded to dividend exemption. Moreover, foreign affiliates that had retained a large amount of profits would be able to flexibly change (increase) dividend payments in response to the tax reform because dividends are from after-tax profits and the stock of retained earnings. We also observe from Table 2 that dividend payments as a proportion of sales increase at the 90th percentile and above in each year after 2009. This suggests that a small portion of foreign affiliates with large dividend payout capacity exhibited a stronger response to dividend exemption. To examine this issue, we investigate the possibility that the heterogeneous response to dividend exemption depends on the magnitude of the retained earnings of the foreign affiliates and examine whether foreign affiliates with a large stock of retained earnings changed dividend payments in a manner consistent with hypotheses H1H3.

We use information on the stock of retained earnings at the end of each fiscal year and 
construct a dummy variable equal to one if the stock of retained earnings when scaled by sales is greater than the value at the 90th percentile in the previous year's sample. ${ }^{37}$ Denote the dummy variable by $R_{i j c t}$, where $i$ is the index for the affiliate owned by parent firm $j$. We first select the threshold at the 90th percentile because we observe in Table 2 that the distribution of dividends scaled by sales increases at the 90 th percentile and above in each year after 2009 .

To consider the heterogeneity of the response to dividend exemption in the regression equation, we estimate equation (5) including the dummy variable $R_{i j c t}$ and the interaction terms of the dummy variable with each of $D E_{t}, P_{i j c t}, w_{c t}^{D},\left(D E_{t} * P_{i j c t}\right)$, and $\left(D E_{t} * w_{c t}^{D}\right)$ as independent variables. We also include year dummies for 2009 to 2011 instead of the postreform dummy $D E_{t}$ itself to capture common yearly changes in dividends for all affiliates after 2009. We specify a set of observations where $R_{i j c t}=1$ as a treatment group and conduct a version of difference-in-differences estimation.

Table 7 presents the estimation results. As in Table 6, columns 1 and 2 report the coefficients estimated by the Tobit procedure and columns 3 and 4 report the results from the fixed-effects OLS. ${ }^{38}$ The coefficient on $R_{i j c t}$ is positive for all specifications and significant at the $1 \%$ level in the Tobit models. ${ }^{39}$ In addition, the coefficient on $\left(R_{i j c t} * D E_{t}\right)$ is significantly positive at the $5 \%$ level in all four specifications. These results suggest that a foreign affiliate with a larger stock of retained earnings in the previous year paid a larger amount of dividends under the worldwide tax system and increased dividend payments further after the dividend exemption system was enacted in 2009. This is consistent with hypothesis H1. The OLS estimates indicate that, after 2009, a foreign affiliate within the top $10 \%$ of retained earnings relative to sales in the previous year paid a larger amount of dividends by about $1 \%$ of its sales than other affiliates holding affiliate sales fixed.

\section{$===$ Table $7===$}

The coefficients on $\left(R_{i j c t} * D E_{t} * w_{c t}^{D}\right)$ are negative and statistically significant at the $1 \%$ level in all specifications. This suggests that a foreign affiliate with a larger stock of retained earnings in the previous year cares more about the tax costs of withholding taxes on dividends after 2009 than other affiliates, which is consistent with hypothesis H3. The fixed-effects OLS estimates imply that if the withholding tax rate on dividends is 1 percentage

\footnotetext{
${ }^{37}$ In the survey, the stock of retained earnings is defined as "Proprietary capital - Capital - Capital reserve."

${ }^{38}$ For the reason described in footnote 34 , we focus on the marginal effect on the latent dependent variable (the desired amount of dividend payments) in the Tobit estimation.

${ }^{39}$ We cannot precisely estimate the coefficient on $R_{i j c t}$ when including affiliate fixed effects, possibly because the composition of foreign affiliates within the top $10 \%$ of retained earnings scaled by sales is stable over time, and thus there is little within-affiliate variation in $R_{i j c t}$.
} 
point higher, a foreign affiliate with a large stock of retained earning reduces its dividend payout by $0.08 \%$ of sales relative to other affiliates after 2009 while holding affiliate sales fixed. The coefficients on $\left(D E_{t} * P_{i j c t}\right)$ and $\left(R_{i j c t} * D E_{t} * P_{i j c t}\right)$ are not estimated statistically significantly positive in any of the specifications, which is still inconsistent with hypothesis H2.

These findings are obscured when we define the dummy variable $R_{i j c t}$ at a lower threshold for the stock of retained earnings. We estimate the same equation after redefining $R_{i j c t}$ as a dummy variable equal to one if the stock of retained earnings scaled by sales is greater than the median value in the previous year's sample. Table 8 provides the estimation results. The estimated coefficient on $\left(R_{i j c t} * D E_{t}\right)$ loses its significance, although remains positive, in the Tobit specifications. In the fixed-effects OLS specifications, the estimated coefficient is significantly positive (0.003) but smaller than that in Table 7 (0.01). We observe a similar tendency for the estimated coefficient on $\left(R_{i j c t} * D E_{t} * w_{c t}^{D}\right) .{ }^{40}$

$$
==\text { Table } 8==
$$

In the above specifications, the value of $R_{i j c t}$ could change over time for each affiliate depending on the size of retained earnings in year $t-1$. We also try defining the dummy variable based on the stock of retained earnings relative to sales in 2007. More precisely, we define dummy variable $R_{i j c, 2007}$, which takes a value of one if the stock of retained earnings scaled by sales is larger than a specific percentile value (the 90th percentile or the median value) in the sample for 2007 , otherwise zero. Then, the value of $R_{i j c, 2007}$ is fixed over time for each affiliate and the foreign affiliates in the sample are split into two groups on the basis of the dummy variable $R_{i j c, 2007}$. We find that the estimation results shown in Tables 7 and 8 do not qualitatively change at all when using $R_{i j c, 2007}$ instead of $R_{i j c t}$. This implies that the foreign affiliates that showed a stronger response to the tax reform are those that had a large stock of retained earnings even before the adoption of a territorial tax regime started to be seriously discussed in 2008. ${ }^{41}$ This also suggests that the composition of foreign affiliates with a large stock of retained earnings $\left(R_{i j c t}=1\right)$ is stable throughout the data collection period.

In summary, the response of Japanese-owned affiliates to dividend exemption was heterogeneous depending on the magnitude of the stock of retained earnings. A small portion

\footnotetext{
${ }^{40}$ We also try setting the threshold for $R_{i j c t}$ at the 95 th and 75 th percentile values. We find that as the threshold level increases from the median to the 75 th, 90th, and 95th percentile values, the absolute values of the estimated coefficients on $\left(R_{i j c t} * D E_{t}\right)$ and $\left(R_{i j c t} * D E_{t} * w_{c t}^{D}\right)$ become larger. This also confirms that foreign affiliates with a larger stock of retained earnings in the previous year were more responsive to the tax reform.

${ }^{41}$ The estimation results are available upon request from the authors.
} 
of foreign affiliates that had a sufficiently large payout capacity responded to dividend exemption in a manner consistent with our hypotheses H1 and H3. The top $10 \%$ of foreign affiliates in terms of retained earnings showed a stronger response to the tax reform because they had sufficient capacity to flexibly change dividends paid from their retained earnings. These affiliates increased their dividend payouts and became more sensitive to withholding tax rates on dividends after 2009. However, we find no evidence that the change in dividend payments is positively associated with the grossed-up tax rate differentials between Japan and foreign countries. This may imply a lack of tax aggressiveness on the part of Japanese corporations. ${ }^{42}$ The Japanese government was concerned that adopting a territorial tax system would facilitate tax avoidance by multinational corporations shifting foreign income to low-tax countries. Our results possibly suggest that Japanese parent firms did not respond to dividend exemption by reallocating their foreign profits to their foreign affiliates in low-tax countries, thereby increasing dividend repatriations from these affiliates after 2009, and thus may alleviate at least this concern of the Japanese government.

\section{Robustness Checks}

In this section, we describe the results of robustness checks to see how sensitive the results presented in the previous section are to different specifications. First, it is possible that because dividend payout capacity increases as the profits of foreign affiliates increase, the significant positive coefficient on $\left(R_{i j c t} * D E_{t}\right)$ may result from an increase in the profitability of foreign affiliates with a large stock of retained earnings after 2009 and not the enactment of dividend exemption. To investigate this, we estimate the same set of regression equations as in Table 7 after replacing the dependent variable with pretax profits scaled by affiliate sales. $^{43}$

Table 9 presents the estimation results. The estimated coefficients on the post-reform year dummy variables $\left(2009,2010\right.$, and 2011) and the interaction term $\left(R_{i j c t} * D E_{t}\right)$ are negative. This suggests that although the profitability of foreign affiliates with a large stock of retained earnings decreased or was unchanged after 2009, they significantly increased their dividend payments scaled by sales, as shown in Table 7 . These results imply that the positive

\footnotetext{
${ }^{42}$ Takashima (2009) argues that; (i) many Japanese corporations lack a full awareness of the importance of international tax and accounting strategies, and thus tend to bear extra tax costs that they could otherwise save, (ii) Japanese companies tend to assume that taxes are unavoidable and are to be paid to the government, while US and European companies regard taxes as costs that they should manage and reduce, and (iii) Japanese corporations lack sufficient human resources for tax planning.

${ }^{43}$ Unlike the estimation equation for dividend payments, there is no issue with the right censoring of the pretax profits of foreign subsidiaries. Thus, we employ ordinary least squares to estimate the pretax profit equation.
} 
effect of dividend exemption on dividend payments by foreign affiliates with a large stock of retained earnings does not result from the improvement in the profitability of the foreign subsidiaries. ${ }^{44}$

$$
==\text { Table } 9==
$$

Second, there could be concerns that the entry and exit of foreign affiliates into and out of the data affect our results. The panel data used for the regression analysis is heavily unbalanced because parent firms do not necessarily report affiliate information in every year of the study period and because, as we explained, there are many missing values for dividend payments. When we restrict foreign affiliates in the sample to only those that consistently appear in the data and report dividend payments in all years from 2007 to 2011, only 4,720 affiliates remain in each year.

This creates more balanced panel data consisting of these 4,720 affiliates. We then estimate the same regression equations as shown in Table 7. Table 10 presents the estimation results using the balanced panel data. Although the sample size is less than half that of the original sample, the results for the key parameters are qualitatively similar to those in Table 7. The estimated coefficient on $\left(R_{i j c t} * D E_{t}\right)$ is statistically significantly positive in all specifications. The estimated coefficient on $\left(R_{i j c t} * D E_{t} * w_{c t}^{D}\right)$ is negative in all specifications, though not statistically significant in the fixed-effects models, possibly because of the contraction of the sample size.

\section{$===$ Table $10==$}

\section{Discussions and Conclusion}

In April 2009, Japan introduced permanent dividend exemption and moved to a territorial tax system. Using confidential survey data for Japanese multinational corporations from 2006 to 2011, we provide the first evidence concerning the behavioral responses of Japaneseowned foreign affiliates to the transition from a worldwide income tax system to a territorial tax system. We find that the response of Japanese-owned affiliates to dividend exemption was heterogeneous, whereby foreign affiliates that retained a large stock of retained earnings in the previous year significantly increased dividend payments to their parent firms in response to Japan's adoption of a territorial tax regime. This implies that dividend exemption helped fulfill its primary aim of stimulating dividend repatriation from foreign affiliates that had amassed large amounts of foreign profits.

\footnotetext{
${ }^{44}$ We also confirm that the estimation results do not change when controlling for affiliate pretax profit scaled by sales in the estimation equations presented in Table 7.
} 
We also examined the changes in the responsiveness of dividends to foreign tax rates, withholding tax rates on dividends, and corporate tax rates in the host countries. Dividend payments by affiliates with a large reserve of retained earnings became more sensitive to withholding tax rates on dividends levied by host countries because Japanese multinationals could no longer claim foreign tax credits for withholding tax payments on repatriated dividends under the new exemption system. This suggests that under the new exemption system, lowering withholding tax rates through revision of existing tax treaties or concluding new tax treaties to lower withholding tax rates on dividends would be a more effective way to stimulate dividend repatriation than before. On the other hand, we found no evidence that the responsiveness of dividend repatriations to foreign corporate tax rates changed with the enactment of dividend exemption. More precisely, the change in dividend payments was not positively associated with the grossed-up tax rate differentials between Japan and the foreign countries after the tax reform.

Our results should be informative for international corporate tax policy debate in the U.S. as well as in other countries that have recently enacted or are contemplating similar reforms. Our findings may be especially relevant to the U.S. because of the similarity between the U.S. and Japanese worldwide tax systems, and given that the two countries have the highest corporate tax rates in the OECD. However, attempts to extend our findings to other countries need to consider carefully the differences in international tax systems and possible differences in cultural attitudes toward tax compliance and general tax morale. ${ }^{45}$ Nonetheless, our findings on the heterogeneous response depending on the stock of retained earnings are worth noting.

\footnotetext{
${ }^{45}$ One notable difference between the U.S. and Japan (before 2009) in the worldwide tax system is that the U.S. tax system requires multinational firms to calculate their foreign tax credits for foreign taxes on passive and active incomes separately, while the Japanese worldwide tax system did not. Another difference is that, unlike the U.S., Japan has tax-sparing agreements with several countries (Bangladesh, Brazil, China, the Philippines, Sri Lanka, Thailand, and Zambia as of June 2012) under bilateral tax treaties, which would serve to reduce the repatriation tax costs for foreign affiliates in these countries.
} 


\section{References}

[1] Ai, Chunrong and Edward C. Norton.2003. "Interaction Terms in Logit and Probit models." Economics Letters 80(1), 123-129.

[2] Altshuler, Rosanne and Harry Grubert. 2001. "Where Will They Go if We Go Territorial? Dividend Exemption and the Location Decisions of U.S. Multinational Corporations." National Tax Journal 54(4), 787-809.

[3] Altshuler, Rosanne and Harry Grubert. 2003. "Repatriation Taxes, Repatriation Strategies and Multinational Financial Policy." Journal of Public Economics 87(1), 73-107.

[4] Aoyama, Keiji. 2009. "A Note on the New Japanese Exemption Policy of Foreign Subsidiary's Dividends (Gaikoku Kogaisha Haito Ekikin Fusannyu Seido no Kosatsu)." Tsukuba Law Journal 6, 99-117 (In Japanese).

[5] Bénassy-Quéré, Agnès, Lionel Fontagné, and Amina Lahrèche-Révil. 2005. "How Does FDI React to Corporate Taxation?" International Tax and Public Finance 12(5), pp. 583-603.

[6] Blouin, Jennifer and Linda Krull. 2009. "Bringing It Home: A Study of the Incentives Surrounding the Repatriation of Foreign Earnings Under the American Jobs Creation Act of 2004." Journal of Accounting Research 47(4), 1027-1059.

[7] Blouin, Jennifer L., Jana Smith Raedy, and Douglas A. Shackelford. 2004. "The Initial Impact of the 2003 Reduction in the Dividend Tax Rate." Working Paper, University of Pennsylvania.

[8] Bradley, Sebastien. 2011. "Round-tripping of Domestic Profits under the American Jobs Creation Act of 2004." NES Working Paper Series No. 201.

[9] Bradley, Sebastien, Estelle Dauchy, and Makoto Hasegawa. 2014. "Investor Valuations of Japan's Adoption of a Territorial Tax Regime: Quantifying the Direct and Competitive Effects of International Tax Reform." Working Paper.

[10] Chetty, Raj and Emmanuel Saez. 2005. "Dividend Taxes and Corporate Behavior: Evidence from the 2003 Dividend Tax Cut." Quarterly Journal of Economics 120(3), 791-833.

[11] Desai, Mihir A., C. Fritz Foley, and James R. Hines Jr. 2001. "Repatriation Taxes and Dividend Distortions." National Tax Journal 54(4), 829-851.

[12] Desai, Mihir A. and James R. Hines Jr. 2004. "Old Rules and New Realities: Corporate Tax Policy in a Global Setting." National Tax Journal 57(4), 937-960. 
[13] Dharmapala, Dhammika, C. Fritz Foley, and Kristin J. Forbes. 2011. "Watch What I Do, Not What I Say: The Unintended Consequences of the Homeland Investment Act." Journal of Finance 66(3), 753-787.

[14] Egger, Peter, Valeria Merlo, Martin Ruf, and Georg Wamser. Forthcoming. "Consequences of the New UK Tax Exemption System: Evidence from Micro-Level Data." Economic Journal.

[15] Greene, William. 2007. Econometric Analysis, 6th Edition. Upper Saddle River, New Jersey: Prentice Hall.

[16] Grubert, Harry. 1998. "Taxes and the Division of Foreign Operating Income among Royalties, Interest, Dividends and Retained Earnings," Journal of Public Economics 68(2), 269-290.

[17] Hartman, David G. 1985. "Tax Policy and Foreign Direct Investment." Journal of Public Economics 26(1), 107-121.

[18] Hines, James R. Jr. 1996. "Altered States: Taxes and the Location of Foreign Direct Investment in America." American Economic Review 86(5), 1076-1094.

[19] Hines, James R., Jr. and R. Glenn Hubbard. 1990. "Coming Home to America: Dividend Repatriations by U.S. Multinationals." In Assaf Razin and Joel Slemrod (eds.), Taxation in the Global Economy, Chicago: University of Chicago Press, 161-200.

[20] Masui, Yoshihiro. 2010. "Taxation of Foreign Subsidiaries: Japan's Tax Reform 2009/10." Bulletin for International Taxation 64(4), 242-248.

[21] Ministry of Economy, Trade and Industry of Japan (METI). 2008a. Repatriations of Foreign Profits by Japanese Enterprises: Toward the introduction of a dividend exemption regime (Wagakuni Kigyo no Kaigairieki no Kanryu nitsuite). August 22, (In Japanese).

[22] Ministry of Economy, Trade and Industry of Japan (METI). 2008b. On the 2009 Tax Reform (Heisei 21 Nendo Zeiseikaisei nitsuite). December, (In Japanese).

[23] Oler, Mitchell, Terry Shevlin, and Ryan Wilson. 2007. "Examining Investor Expectations concerning Tax Savings on the Repatriations of Foreign Earnings under the American Jobs Creation Act of 2004." Journal of the American Taxation Association $29(2), 25-55$.

[24] Organisation for Economic Co-operation and Development (OECD). 2010. OECD Tax Database, Paris: OECD. 
[25] PricewaterhouseCoopers (PwC). 2013. "Evolution of Territorial Tax Systems in the OECD." Prepared for The Technology CEO Council.

[26] Redmiles, Melissa. 2008. "The One-Time Received Dividend Deduction." Statistics of Income Bulletin, 102-114.

[27] Sakurada, Joe and Yoshiyuki Nakanishi. 2011. "The Stock Market Reaction to the Announcement Regarding Japan's Foreign Dividend Exemption (Gaikoku Kogaisha Rieki no Kokunai Kanryu ni kansuru Zeiseikaisei to Shijo no Hanno)." Working Paper, Hokkaido University. (In Japanese).

[28] Slemrod, Joel. 1990. "Tax Effects on Foreign Direct Investment in the United States: Evidence From a Cross-Country Comparison," in Assaf Razin and Joel Slemrod (eds.), Taxation in the Global Economy, Chicago, IL: University of Chicago Press, $79-117$.

[29] Tajika, Eiji, Masaki Hotei, and Keiko Shibata. 2014. "The Effects of DividendExemption Method on Repatriation of Income from Abroad: The Case of 2009 Japanese Tax Reform (Zeisei to Kaigai Kogaisha no Rieki Sokin: Honsha Shikin Juyo Karamita 2009 Nendo Kaisei no Bunseki)." Economic Analysis (Keizai Bunseki). (In Japanese).

[30] Tajika, Eiji and Ryota Nakatani. 2008. "Welcome Home to Japan: Repatriation of Foreign Profits by Japanese Multinationals." Discussion Paper No. 2008-04, Hitotsubashi University.

[31] Takashima, Kennichi. 2009. "The Basics of International Tax and Accounting Strategies: The Importance of International Tax and Accounting Strategies for Business Operation (Kokusai Zeimu Senryaku no Kiso: Keiei Senryaku niokeru Kokusai Zeimu no Juyousei)," (in Japanese), available at http://www.kpmg.com/Jp/ja/knowledge/ article/tax/Documents/200907_2.pdf.

[32] United Nations Conference on Trade and Development (UNCTAD). 2012. UNCTADStat Database, http://unctadstat.unctad.org/ReportFolders/reportFolders.aspx. 
Table 1: Dividend Payments by Foreign Affiliates (in million yen)

\begin{tabular}{rrrrrrrrrr}
\hline year & sum & mean & sd & p50 & p75 & p90 & p95 & p99 & N \\
\hline 2007 & 1214686 & 129 & 1480 & 0 & 12 & 138 & 350 & 2178 & 9399 \\
2008 & 1020855 & 100 & 882 & 0 & 6 & 105 & 302 & 1624 & 10178 \\
2009 & 1466062 & 146 & 2283 & 0 & 2 & 94 & 257 & 1643 & 10048 \\
2010 & 991675 & 97 & 868 & 0 & 5 & 99 & 293 & 1694 & 10224 \\
2011 & 1472833 & 136 & 2886 & 0 & 9 & 125 & 340 & 1883 & 10818 \\
Total & 6166111 & 122 & 1878 & 0 & 6 & 111 & 310 & 1808 & 50667 \\
\hline
\end{tabular}

Table 2: Dividend Payments by Foreign Affiliates as a Proportion of Sales

\begin{tabular}{lrrrrrrrr}
\hline year & mean & sd & p50 & p75 & p90 & p95 & p99 & $\mathbf{N}$ \\
\hline 2007 & .0465 & 1.24 & 0 & .00546 & .032 & .0623 & .213 & 8985 \\
2008 & .0241 & .711 & 0 & .00419 & .0312 & .0638 & .219 & 9675 \\
2009 & .0404 & 1.32 & 0 & .00258 & .0361 & .0768 & .295 & 9506 \\
2010 & .0425 & 1.29 & 0 & .00476 & .0329 & .0651 & .247 & 9343 \\
2011 & .0483 & 1.47 & 0 & .00699 & .0391 & .0744 & .276 & 9915 \\
Total & .0403 & 1.24 & 0 & .0049 & .0339 & .0682 & .253 & 47424 \\
\hline
\end{tabular}

Table 3: Proportion of Foreign Affiliates Paying Dividends

\begin{tabular}{ccccc}
\hline Year & Dividend $>0$ & Dividend $=0$ & Total Number of Affiliates & Proportion \\
\hline 2007 & 2836 & 6563 & 9399 & $30.2 \%$ \\
2008 & 2881 & 7297 & 10178 & $28.3 \%$ \\
2009 & 2604 & 7444 & 10048 & $25.9 \%$ \\
2010 & 2834 & 7390 & 10224 & $27.7 \%$ \\
2011 & 3207 & 7611 & 10818 & $29.6 \%$ \\
\hline Total & 14362 & 36305 & 50667 & $28.3 \%$ \\
\hline
\end{tabular}


Table 4: Definitions of Variables

\begin{tabular}{ll}
\hline Variable & Definition \\
\hline Sales $_{i j c t}$ & Subsidiary operating revenues without in- \\
& cluding non-operating income \\
$(\text { Dividend/Sales })_{i j c t}$ & Subsidiary dividend payments scaled by sales \\
$P_{i j c t}$ & Grossed-up difference between Japanese \\
& statutory tax rate and the subsidiary aver- \\
& age tax rate \\
& Withholding tax rate on dividends \\
$w_{c t}^{D}$ & Withholding tax rate on royalties \\
$w_{c t}^{R}$ & Withholding tax rate on interest \\
$w_{c t}^{I}$ & Average subsidiary tax rate, which is defined \\
$\hat{\tau}_{i j c t}$ & as the corporate tax payment divided by the \\
& pretax profit of subsidiary $i$ \\
$\tau_{c t}$ & Statutory corporate tax rate \\
Foreign Exchange Rate & Exchange rate between Japanese yen and lo- \\
& cal currency, which is normalized to one in \\
& 2005 \\
Real GDP Growth & Real GDP Growth Rate \\
$(\text { Parent Net Profit/Assets })_{i j c t}$ & Parent net profit scaled by total assets \\
$(\text { Parent Debt/Assets })_{i j c t}$ & Parent total debt (total current and fixed li- \\
& abilities) scaled by total assets \\
Retained Earnings & Fiscal year-end balance of retained earnings, \\
& which is defined as "Proprietary capital - \\
& Capital - Capital reserve" \\
(Retained Earnings/Sales $)_{i j c t}$ & Subsidiary retained earnings at the end of the \\
& account year scaled by sales \\
(Profit/Sales $)_{i j c t}$ & Subsidiary pre-tax profit divided by sales \\
\hline
\end{tabular}

Notes: The subscripts $i, j, c$, and $t$ indicate the subsidiary, its parent firm, the country where the subsidiary is located, and the year, respectively. 
Table 5: Descriptive Statistics

\begin{tabular}{|c|c|c|c|c|c|c|}
\hline ariable & mean & sd & p25 & p50 & p75 & $\mathbf{N}$ \\
\hline$\overline{(\text { Dividend/Sales) }}{ }_{i j c t}$ & .0122 & .0361 & 0 & 0 & .0049 & 47424 \\
\hline$P_{i j c t}$ & .257 & .165 & .166 & .298 & 407 & 2197 \\
\hline$w_{c t}^{D}$ & .0686 & .0658 & 0 & .1 & .1 & 6573 \\
\hline$w_{c t}^{R}$ & .0886 & .0592 & .0525 & .1 & .1 & $65^{\prime}$ \\
\hline$w^{I}$ & .103 & .0459 & .1 & .1 & $x$ & 65 \\
\hline ijct & .219 & 1.56 & 0 & .156 & .289 & 21 \\
\hline & 5 & .07 & 25 & 28 & .33 & 365 \\
\hline rei & 1.05 & .184 & .922 & 1.03 & 1.15 & 365 \\
\hline eal GDF & 5.1 & 4.59 & 1.85 & 5.04 & 9.2 & 62 \\
\hline Parent Net I & .0152 & .0478 & .00409 & .0187 & .0377 & 863 \\
\hline Parent Debt/ & .57 & .215 & .408 & .592 & .746 & 866 \\
\hline d Earnings/Sales) & .0418 & .95 & -.00796 & .0844 & .268 & 623 \\
\hline$\left(\right.$ Profit/Sales) ${ }_{i j c t}$ & .0147 & .289 & .00309 & .0357 & .092 & 704 \\
\hline
\end{tabular}

Notes: The subscripts $i, j, c$, and $t$ indicate the subsidiary, its parent firm, the country where the subsidiary is located, and the year, respectively. See Table 4 for the definition of each variable. 
Table 6: Regressions of the Dividend Equation

\begin{tabular}{|c|c|c|c|c|}
\hline & & (Dividend & Sales) $)_{i j c t}$ & \\
\hline & $(1)$ & $(2)$ & $(3)$ & $(4)$ \\
\hline$D E_{t}$ & 0.0020 & 0.0044 & $0.0050^{* *}$ & $0.0049^{*}$ \\
\hline & $(0.0068)$ & $(0.0074)$ & $(0.0025)$ & $(0.0028)$ \\
\hline$P_{i j c t}$ & $-0.1064^{* * *}$ & $-0.1012^{* * *}$ & 0.0023 & 0.0019 \\
\hline & $(0.0051)$ & $(0.0056)$ & $(0.0017)$ & $(0.0019)$ \\
\hline$D E_{t} * P_{i j c t}$ & -0.0048 & -0.0070 & $-0.0040^{* *}$ & -0.0019 \\
\hline & $(0.0058)$ & $(0.0064)$ & $(0.0019)$ & $(0.0022)$ \\
\hline$w_{c t}^{D}$ & -0.0537 & -0.0698 & 0.0030 & 0.0079 \\
\hline & $(0.0464)$ & $(0.0500)$ & $(0.0230)$ & $(0.0259)$ \\
\hline$D E_{t} * w_{c t}^{D}$ & -0.0196 & -0.0188 & $-0.0196^{* *}$ & $-0.0276^{* * *}$ \\
\hline & $(0.0216)$ & $(0.0231)$ & $(0.0084)$ & $(0.0095)$ \\
\hline$w_{c t}^{R}$ & -0.0535 & -0.0447 & $-0.0319^{* *}$ & $-0.0455^{* *}$ \\
\hline & $(0.0422)$ & $(0.0449)$ & $(0.0157)$ & $(0.0197)$ \\
\hline$D E_{t} * w_{c t}^{R}$ & 0.0135 & -0.0005 & 0.0115 & 0.0093 \\
\hline & $(0.0363)$ & $(0.0389)$ & $(0.0125)$ & $(0.0139)$ \\
\hline$w_{c t}^{I}$ & 0.0440 & 0.0433 & -0.0170 & -0.0311 \\
\hline & $(0.0742)$ & $(0.0714)$ & $(0.0515)$ & $(0.0532)$ \\
\hline$D E_{t} * w_{c t}^{I}$ & -0.0177 & 0.0006 & -0.0035 & 0.0129 \\
\hline & $(0.0395)$ & $(0.0424)$ & $(0.0143)$ & $(0.0156)$ \\
\hline$\tau_{c t}$ & -0.0378 & -0.0171 & 0.0035 & 0.0023 \\
\hline & $(0.0270)$ & $(0.0290)$ & $(0.0102)$ & $(0.0114)$ \\
\hline$D E_{t} * \tau_{c t}$ & 0.0012 & 0.0091 & -0.0089 & -0.0117 \\
\hline & $(0.0214)$ & $(0.0230)$ & $(0.0079)$ & $(0.0087)$ \\
\hline Foreign Exchange Rate ${ }_{c t}$ & $0.0188^{* * *}$ & 0.0097 & $0.0039^{*}$ & 0.0032 \\
\hline & $(0.0060)$ & $(0.0066)$ & $(0.0023)$ & $(0.0026)$ \\
\hline Real GDP Growth Rate $c t$ & $0.0003^{*}$ & 0.0000 & $-0.0002^{* *}$ & $-0.0002^{* * *}$ \\
\hline & $(0.0002)$ & $(0.0002)$ & $(0.0001)$ & $(0.0001)$ \\
\hline Year 2008 & -0.0010 & 0.0003 & -0.0003 & -0.0002 \\
\hline & $(0.0016)$ & $(0.0017)$ & $(0.0006)$ & $(0.0007)$ \\
\hline Lagged (Parent Net Profit/Assets) $i j c t$ & & $0.0862^{* * *}$ & & 0.0014 \\
\hline & & $(0.0153)$ & & $(0.0065)$ \\
\hline Lagged (Parent Debt/Assets) ${ }_{i j c t}$ & & $-0.0158^{* * *}$ & & 0.0061 \\
\hline & & $(0.0041)$ & & $(0.0040)$ \\
\hline Constant & $-0.0478^{* *}$ & -0.0355 & $0.0118^{*}$ & $0.0124^{*}$ \\
\hline & $(0.0211)$ & $(0.0232)$ & $(0.0065)$ & $(0.0074)$ \\
\hline Country and Industry Dummies & Yes & Yes & No & No \\
\hline Affiliate Fixed Effects & No & No & Yes & Yes \\
\hline Tobit or OLS & Tobit & Tobit & OLS & OLS \\
\hline Observations & 42,181 & 34,819 & 42,181 & 34,819 \\
\hline R-squared & & & 0.0031 & 0.0042 \\
\hline
\end{tabular}


Table 7: Dividend Equation Including the Stock of Retained Earnings (the 90th percentile threshold)

\begin{tabular}{|c|c|c|c|c|}
\hline & \multicolumn{4}{|c|}{ (Dividend/Sales) ${ }_{i j c t}$} \\
\hline & $(1)$ & $(2)$ & $(3)$ & $(4)$ \\
\hline \multirow[t]{2}{*}{ Year 2009} & 0.0069 & 0.0090 & $0.0050^{*}$ & $0.0055^{*}$ \\
\hline & $(0.0076)$ & $(0.0076)$ & $(0.0030)$ & $(0.0030)$ \\
\hline \multirow[t]{2}{*}{ Year 2010} & 0.0043 & 0.0053 & 0.0041 & 0.0044 \\
\hline & $(0.0076)$ & $(0.0076)$ & $(0.0030)$ & $(0.0030)$ \\
\hline \multirow[t]{2}{*}{ Year 2011} & 0.0129 & 0.0124 & $0.0060^{*}$ & $0.0064^{* *}$ \\
\hline & $(0.0079)$ & $(0.0079)$ & $(0.0032)$ & $(0.0032)$ \\
\hline \multirow[t]{2}{*}{$R_{i j c t}$} & $0.0286^{* * *}$ & $0.0281^{* * *}$ & 0.0008 & 0.0009 \\
\hline & $(0.0067)$ & $(0.0068)$ & $(0.0037)$ & $(0.0037)$ \\
\hline \multirow[t]{2}{*}{$R_{i j c t} * D E_{t}$} & $0.0183^{* *}$ & $0.0181^{* *}$ & $0.0095^{* *}$ & $0.0096^{* *}$ \\
\hline & $(0.0077)$ & $(0.0078)$ & $(0.0043)$ & $(0.0044)$ \\
\hline \multirow[t]{2}{*}{$P_{i j c t}$} & $-0.1020^{* * *}$ & $-0.1011^{* * *}$ & 0.0008 & 0.0008 \\
\hline & $(0.0055)$ & $(0.0056)$ & $(0.0018)$ & $(0.0018)$ \\
\hline \multirow[t]{2}{*}{$D E_{t} * P_{i j c t}$} & -0.0031 & -0.0027 & 0.0002 & 0.0004 \\
\hline & $(0.0063)$ & $(0.0063)$ & $(0.0020)$ & $(0.0021)$ \\
\hline \multirow{2}{*}{$R_{i j c t} * P_{i j c t}$} & $0.0725^{* * *}$ & $0.0720^{* * *}$ & 0.0018 & 0.0023 \\
\hline & $(0.0227)$ & $(0.0227)$ & $(0.0112)$ & $(0.0114)$ \\
\hline \multirow[t]{2}{*}{$R_{i j c t} * D E_{t} * P_{i j c t}$} & $-0.0465^{*}$ & $-0.0447^{*}$ & -0.0033 & -0.0033 \\
\hline & $(0.0265)$ & $(0.0266)$ & $(0.0143)$ & $(0.0145)$ \\
\hline \multirow[t]{2}{*}{$w_{c t}^{D}$} & -0.0466 & -0.0513 & 0.0153 & 0.0167 \\
\hline & $(0.0495)$ & $(0.0494)$ & $(0.0238)$ & $(0.0239)$ \\
\hline \multirow[t]{2}{*}{$D E_{t} * w_{c t}^{D}$} & -0.0034 & -0.0053 & $-0.0161^{*}$ & $-0.0183^{*}$ \\
\hline & $(0.0237)$ & $(0.0239)$ & $(0.0094)$ & $(0.0096)$ \\
\hline \multirow[t]{2}{*}{$R_{i j c t} * w_{c t}^{D}$} & $0.0777^{*}$ & 0.0737 & $0.0560^{*}$ & $0.0520^{*}$ \\
\hline & $(0.0467)$ & $(0.0467)$ & $(0.0291)$ & $(0.0291)$ \\
\hline \multirow{2}{*}{$R_{i j c t} * D E_{t} * w_{c t}^{D}$} & $-0.1314^{* * *}$ & $-0.1311^{* * *}$ & $-0.0774^{* * *}$ & $-0.0791^{* * *}$ \\
\hline & $(0.0497)$ & $(0.0497)$ & $(0.0297)$ & $(0.0298)$ \\
\hline \multirow[t]{2}{*}{$w_{c t}^{R}$} & $-0.0784^{*}$ & $-0.0747^{*}$ & $-0.0455^{* *}$ & $-0.0465^{* *}$ \\
\hline & $(0.0438)$ & $(0.0439)$ & $(0.0201)$ & $(0.0202)$ \\
\hline \multirow{2}{*}{$D E_{t} * w_{c t}^{R}$} & 0.0027 & 0.0022 & 0.0065 & 0.0069 \\
\hline & $(0.0394)$ & $(0.0395)$ & $(0.0145)$ & $(0.0146)$ \\
\hline \multirow[t]{2}{*}{$w_{c t}^{I}$} & -0.0521 & -0.0534 & -0.0360 & -0.0368 \\
\hline & $(0.0751)$ & $(0.0747)$ & $(0.0551)$ & $(0.0555)$ \\
\hline \multirow[t]{2}{*}{$D E_{t} * w_{c t}^{I}$} & 0.0112 & 0.0125 & 0.0155 & 0.0151 \\
\hline & $(0.0424)$ & $(0.0425)$ & $(0.0159)$ & $(0.0161)$ \\
\hline \multirow{2}{*}{$\tau_{c t}$} & 0.0157 & 0.0119 & 0.0078 & 0.0071 \\
\hline & $(0.0299)$ & $(0.0300)$ & $(0.0121)$ & $(0.0122)$ \\
\hline$D E_{t} * \tau_{c t}$ & -0.0039 & -0.0011 & -0.0120 & -0.0127 \\
\hline & $(0.0232)$ & $(0.0232)$ & $(0.0090)$ & $(0.0091)$ \\
\hline Foreign Exchange Rate $_{c t}$ & -0.0055 & -0.0045 & -0.0017 & -0.0019 \\
\hline & $(0.0080)$ & $(0.0081)$ & $(0.0034)$ & $(0.0034)$ \\
\hline Real GDP Growth Rate $c t$ & 0.0004 & 0.0004 & -0.0001 & -0.0001 \\
\hline & $(0.0002)$ & $(0.0002)$ & $(0.0001)$ & $(0.0001)$ \\
\hline Year 2008 & $0.0032^{*}$ & $0.0032^{*}$ & 0.0010 & 0.0010 \\
\hline & $(0.0019)$ & $(0.0019)$ & $(0.0008)$ & $(0.0008)$ \\
\hline Constant & -0.0377 & -0.0316 & $0.0174^{* *}$ & $0.0152^{*}$ \\
\hline & $(0.0233)$ & $(0.0236)$ & $(0.0073)$ & $(0.0078)$ \\
\hline Parent Controls & No & Yes & No & Yes \\
\hline Country and Industry Dummies & Yes & Yes & No & No \\
\hline Affiliate Fixed Effects & No & No & Yes & Yes \\
\hline Tobit or OLS & Tobit & Tobit & OLS & OLS \\
\hline Observations & 32,829 & 32,565 & 32,829 & 32,565 \\
\hline R-squared & & & 0.0077 & 0.0080 \\
\hline
\end{tabular}


Table 8: Dividend Equation Including the Stock of Retained Earnings (the median threshold)

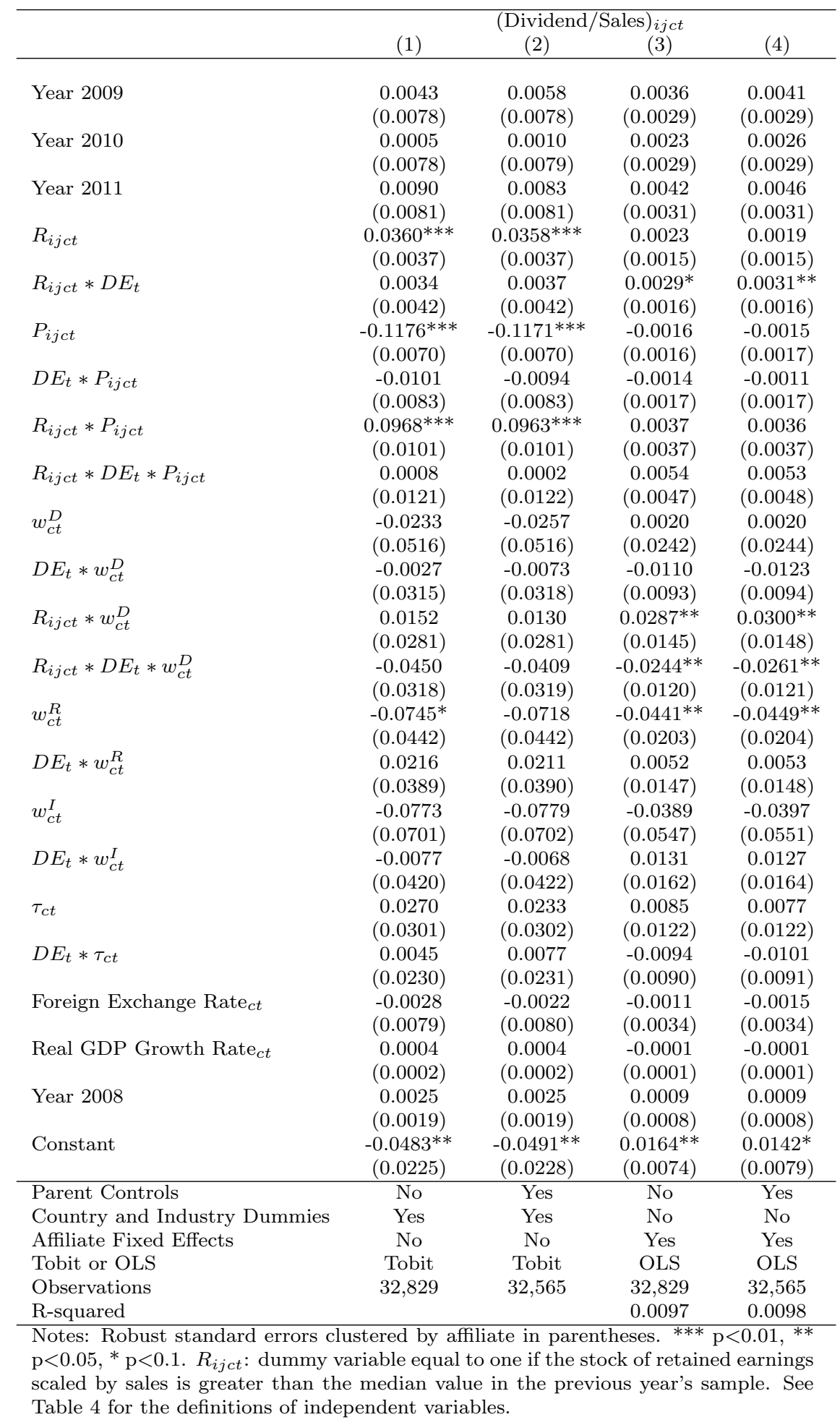




\section{Table 9: Regressions of Profit-Sales Ratios}

\begin{tabular}{|c|c|c|c|c|}
\hline & \multicolumn{4}{|c|}{ (Profit/Sales) ${ }_{i j c t}$} \\
\hline & (1) & & (3) & (4) \\
\hline Year 2009 & $\begin{array}{c}-0.070^{* * *} \\
(0.017)\end{array}$ & $\begin{array}{c}-0.065^{* * *} \\
(0.018)\end{array}$ & $\begin{array}{c}-0.0718^{* * *} \\
(0.0176)\end{array}$ & $\begin{array}{c}-0.0714^{* * *} \\
(0.0177)\end{array}$ \\
\hline Year 2010 & $\begin{array}{c}-0.040^{* *} \\
(0.017)\end{array}$ & $\begin{array}{c}-0.036^{* *} \\
(0.018)\end{array}$ & $\begin{array}{c}-0.0537 * * * \\
(0.0179)\end{array}$ & $\begin{array}{c}-0.0527^{* * *} \\
(0.0180)\end{array}$ \\
\hline Year 2011 & $\begin{array}{c}-0.048^{* * * *} \\
(0.018)\end{array}$ & $\begin{array}{c}-0.046^{* *} \\
(0.018)\end{array}$ & $\begin{array}{c}-0.0632^{* * *} \\
(0.0187)\end{array}$ & $\begin{array}{c}-0.0621^{* * *} \\
(0.0188)\end{array}$ \\
\hline$R_{i j c t}$ & $\begin{array}{c}0.130^{* * *} \\
(0.014)\end{array}$ & $\begin{array}{c}0.130 * * * \\
(0.014)\end{array}$ & $\begin{array}{c}0.0178 \\
(0.0129)\end{array}$ & $\begin{array}{c}0.0182 \\
(0.0130)\end{array}$ \\
\hline$R_{i j c t} * D E_{t}$ & $\begin{array}{l}-0.011 \\
(0.015)\end{array}$ & $\begin{array}{l}-0.012 \\
(0.015)\end{array}$ & $\begin{array}{c}-0.0553^{* * *} \\
(0.0116)\end{array}$ & $\begin{array}{c}-0.0566^{* * *} \\
(0.0117)\end{array}$ \\
\hline$P_{i j c t}$ & $\begin{array}{c}-0.260^{* * *} \\
(0.013)\end{array}$ & $\begin{array}{c}-0.254^{* * *} \\
(0.013)\end{array}$ & $\begin{array}{c}-0.0842^{* * *} \\
(0.0108)\end{array}$ & $\begin{array}{c}-0.0826^{* * *} \\
(0.0108)\end{array}$ \\
\hline$D E_{t} * P_{i j c t}$ & $\begin{array}{c}0.044^{* * *} \\
(0.015)\end{array}$ & $\begin{array}{c}0.040^{* * * *} \\
(0.015)\end{array}$ & $\begin{array}{c}0.0675^{* * *} \\
(0.0138)\end{array}$ & $\begin{array}{c}0.0651^{* * *} \\
(0.0138)\end{array}$ \\
\hline$R_{i j c t} * P_{i j c t}$ & $\begin{array}{l}-0.010 \\
(0.061)\end{array}$ & $\begin{array}{l}-0.014 \\
(0.061)\end{array}$ & $\begin{array}{l}-0.0140 \\
(0.0442)\end{array}$ & $\begin{array}{l}-0.0161 \\
(0.0446)\end{array}$ \\
\hline$R_{i j c t} * D E_{t} * P_{i j c t}$ & $\begin{array}{l}-0.075 \\
(0.069)\end{array}$ & $\begin{array}{l}-0.067 \\
(0.069)\end{array}$ & $\begin{array}{l}-0.0358 \\
(0.0568)\end{array}$ & $\begin{array}{l}-0.0290 \\
(0.0573)\end{array}$ \\
\hline$w_{c t}^{D}$ & $\begin{array}{l}-0.213 \\
(0.131)\end{array}$ & $\begin{array}{l}-0.205 \\
(0.132)\end{array}$ & $\begin{array}{l}-0.1135 \\
(0.1080)\end{array}$ & $\begin{array}{l}-0.1134 \\
(0.1087)\end{array}$ \\
\hline$D E_{t} * w_{c t}^{D}$ & $\begin{array}{l}-0.022 \\
(0.054)\end{array}$ & $\begin{array}{l}-0.031 \\
(0.054)\end{array}$ & $\begin{array}{l}-0.0648 \\
(0.0443)\end{array}$ & $\begin{array}{l}-0.0695 \\
(0.0445)\end{array}$ \\
\hline$R_{i j c t} * w_{c t}^{D}$ & $\begin{array}{c}0.120 \\
(0.105)\end{array}$ & $\begin{array}{c}0.114 \\
(0.105)\end{array}$ & $\begin{array}{l}-0.0232 \\
(0.0918)\end{array}$ & $\begin{array}{l}-0.0261 \\
(0.0923)\end{array}$ \\
\hline$R_{i j c t} * D E_{t} * w_{c t}^{D}$ & $\begin{array}{l}-0.028 \\
(0.127)\end{array}$ & $\begin{array}{l}-0.012 \\
(0.127)\end{array}$ & $\begin{array}{c}0.2270^{* *} \\
(0.0951)\end{array}$ & $\begin{array}{c}0.2309 * * \\
(0.0955)\end{array}$ \\
\hline$w_{c t}^{R}$ & $\begin{array}{l}-0.008 \\
(0.087)\end{array}$ & $\begin{array}{l}-0.010 \\
(0.087)\end{array}$ & $\begin{array}{l}-0.0826 \\
(0.0960)\end{array}$ & $\begin{array}{l}-0.0846 \\
(0.0964)\end{array}$ \\
\hline$D E_{t} * w_{c t}^{R}$ & $\begin{array}{l}0.134^{*} \\
(0.079)\end{array}$ & $\begin{array}{l}0.131^{*} \\
(0.079)\end{array}$ & $\begin{array}{c}0.1599 * * \\
(0.0734)\end{array}$ & $\begin{array}{c}0.1614^{* *} \\
(0.0738)\end{array}$ \\
\hline$w_{c t}^{I}$ & $\begin{array}{l}-0.045 \\
(0.118)\end{array}$ & $\begin{array}{l}-0.052 \\
(0.119)\end{array}$ & $\begin{array}{c}-0.0722 \\
(0.0886)\end{array}$ & $\begin{array}{l}-0.0688 \\
(0.0915)\end{array}$ \\
\hline$D E_{t} * w_{c t}^{I}$ & $\begin{array}{l}-0.019 \\
(0.078)\end{array}$ & $\begin{array}{l}-0.014 \\
(0.078)\end{array}$ & $\begin{array}{c}-0.0351 \\
(0.0653)\end{array}$ & $\begin{array}{l}-0.0350 \\
(0.0658)\end{array}$ \\
\hline$\tau_{c t}$ & $\begin{array}{c}-0.183^{* * *} \\
(0.069)\end{array}$ & $\begin{array}{c}-0.183^{* * *} \\
(0.069)\end{array}$ & $\begin{array}{c}-0.1623^{* * *} \\
(0.0580)\end{array}$ & $\begin{array}{c}-0.1610^{* * *} \\
(0.0584)\end{array}$ \\
\hline$D E_{t} * \tau_{c t}$ & $\begin{array}{c}0.053 \\
(0.048)\end{array}$ & $\begin{array}{c}0.055 \\
(0.048)\end{array}$ & $\begin{array}{c}0.0611 \\
(0.0459)\end{array}$ & $\begin{array}{c}0.0598 \\
(0.0463)\end{array}$ \\
\hline Foreign Exchange Rate $_{c t}$ & $\begin{array}{c}0.053^{* * *} \\
(0.019)\end{array}$ & $\begin{array}{c}0.053^{* * *} \\
(0.019)\end{array}$ & $\begin{array}{c}0.0584^{* * *} \\
(0.0201)\end{array}$ & $\begin{array}{c}0.0587^{* * *} * \\
(0.0201)\end{array}$ \\
\hline Real GDP Growth Rate $c t$ & $\begin{array}{l}-0.001 \\
(0.001)\end{array}$ & $\begin{array}{c}-0.001^{*} \\
(0.001)\end{array}$ & $\begin{array}{l}-0.0004 \\
(0.0004)\end{array}$ & $\begin{array}{l}-0.0004 \\
(0.0004)\end{array}$ \\
\hline Year 2008 & $\begin{array}{c}-0.023^{* * *} \\
(0.004)\end{array}$ & $\begin{array}{c}-0.023^{* * *} \\
(0.004)\end{array}$ & $\begin{array}{c}-0.0246^{* * *} \\
(0.0041)\end{array}$ & $\begin{array}{c}-0.0247^{* * *} \\
(0.0042)\end{array}$ \\
\hline Constant & $\begin{array}{c}0.073 \\
(0.057)\end{array}$ & $\begin{array}{l}0.089^{*} \\
(0.053)\end{array}$ & $\begin{array}{c}0.0939^{* * *} * \\
(0.0244)\end{array}$ & $\begin{array}{c}0.0741^{* * *} * \\
(0.0270)\end{array}$ \\
\hline Parent Controls & No & Yes & No & Yes \\
\hline Country and Industry Dummies & Yes & Yes & No & No \\
\hline Affiliate Fixed Effects & No & No & Yes & Yes \\
\hline Observations & 36,511 & 36,220 & 36,511 & 36,220 \\
\hline R-squared & 0.102 & 0.103 & 0.0128 & 0.0129 \\
\hline
\end{tabular}


Table 10: Dividend Regression Equation using the Balanced Panel Data

\begin{tabular}{|c|c|c|c|c|}
\hline & (1) & $\begin{array}{l}\text { (Dividend } \\
(2)\end{array}$ & $\begin{array}{c}\text { ales) } \text { ijct } \\
\text { (3) }\end{array}$ & (4) \\
\hline Year 2009 & $\begin{array}{c}0.0044 \\
(0.0084)\end{array}$ & $\begin{array}{c}0.0061 \\
(0.0084)\end{array}$ & $\begin{array}{c}0.0041 \\
(0.0033)\end{array}$ & $\begin{array}{c}0.0047 \\
(0.0034)\end{array}$ \\
\hline Year 2010 & $\begin{array}{c}0.0039 \\
(0.0084)\end{array}$ & $\begin{array}{c}0.0046 \\
(0.0084)\end{array}$ & $\begin{array}{c}0.0027 \\
(0.0033)\end{array}$ & $\begin{array}{c}0.0030 \\
(0.0034)\end{array}$ \\
\hline Year 2011 & $\begin{array}{l}0.0119 \\
(0.0088)\end{array}$ & $\begin{array}{l}0.0119 \\
(0.0088)\end{array}$ & $\begin{array}{l}0.0053 \\
(0.0035)\end{array}$ & $\begin{array}{l}0.0057 \\
(0.0036)\end{array}$ \\
\hline$R_{i j c t}$ & $\begin{array}{c}0.0263 * * * \\
(0.0088)\end{array}$ & $\begin{array}{c}0.0259 * * * \\
(0.0088)\end{array}$ & $\begin{array}{l}-0.0011 \\
(0.0041)\end{array}$ & $\begin{array}{l}-0.0007 \\
(0.0041)\end{array}$ \\
\hline$R_{i j c t} * D E_{t}$ & $\begin{array}{c}0.0188^{* *} \\
(0.0093)\end{array}$ & $\begin{array}{l}0.0180^{*} \\
(0.0093)\end{array}$ & $\begin{array}{c}0.0126 * * * \\
(0.0048)\end{array}$ & $\begin{array}{c}0.0122^{* *} \\
(0.0049)\end{array}$ \\
\hline$P_{i j c t}$ & $\begin{array}{c}-0.1083^{* * *} \\
(0.0076)\end{array}$ & $\begin{array}{c}-0.1076^{* * *} \\
(0.0076)\end{array}$ & $\begin{array}{l}-0.0001 \\
(0.0024)\end{array}$ & $\begin{array}{l}-0.0002 \\
(0.0024)\end{array}$ \\
\hline$D E_{t} * P_{i j c t}$ & $\begin{array}{c}0.0099 \\
(0.0081)\end{array}$ & $\begin{array}{c}0.0105 \\
(0.0081)\end{array}$ & $\begin{array}{l}0.0020 \\
(0.0024)\end{array}$ & $\begin{array}{l}0.0021 \\
(0.0025)\end{array}$ \\
\hline$R_{i j c t} * P_{i j c t}$ & $\begin{array}{c}0.0875^{* * * *} \\
(0.0296)\end{array}$ & $\begin{array}{c}0.0874^{* * * *} \\
(0.0297)\end{array}$ & $\begin{array}{l}0.0151 \\
(0.0130)\end{array}$ & $\begin{array}{c}0.0144 \\
(0.0131)\end{array}$ \\
\hline$R_{i j c t} * D E_{t} * P_{i j c t}$ & $\begin{array}{l}-0.0551^{*} \\
(0.0321)\end{array}$ & $\begin{array}{l}-0.0558^{*} \\
(0.0323)\end{array}$ & $\begin{array}{l}-0.0241 \\
(0.0161)\end{array}$ & $\begin{array}{l}-0.0230 \\
(0.0163)\end{array}$ \\
\hline$w_{c t}^{D}$ & $\begin{array}{l}0.0016 \\
(0.0540)\end{array}$ & $\begin{array}{c}0.0017 \\
(0.0538)\end{array}$ & $\begin{array}{l}-0.0035 \\
(0.0261)\end{array}$ & $\begin{array}{l}-0.0030 \\
(0.0262)\end{array}$ \\
\hline$D E_{t} * w_{c t}^{D}$ & $\begin{array}{l}-0.0344 \\
(0.0261)\end{array}$ & $\begin{array}{l}-0.0360 \\
(0.0263)\end{array}$ & $\begin{array}{l}-0.0195^{*} \\
(0.0106)\end{array}$ & $\begin{array}{l}-0.0211^{*} \\
(0.0108)\end{array}$ \\
\hline$R_{i j c t} * w_{c t}^{D}$ & $\begin{array}{c}0.0336 \\
(0.0568)\end{array}$ & $\begin{array}{c}0.0320 \\
(0.0569)\end{array}$ & $\begin{array}{c}0.0683^{* *} \\
(0.0340)\end{array}$ & $\begin{array}{l}0.0670^{*} \\
(0.0342)\end{array}$ \\
\hline$R_{i j c t} * D E_{t} * w_{c t}^{D}$ & $\begin{array}{l}-0.0995^{*} \\
(0.0558)\end{array}$ & $\begin{array}{l}-0.0938^{*} \\
(0.0561)\end{array}$ & $\begin{array}{l}-0.0510 \\
(0.0325)\end{array}$ & $\begin{array}{l}-0.0493 \\
(0.0327)\end{array}$ \\
\hline$w_{c t}^{R}$ & $\begin{array}{c}-0.1108^{* *} \\
(0.0496)\end{array}$ & $\begin{array}{c}-0.1102^{* *} \\
(0.0497)\end{array}$ & $\begin{array}{c}-0.0467^{* *} \\
(0.0229)\end{array}$ & $\begin{array}{c}-0.0477^{* *} \\
(0.0230)\end{array}$ \\
\hline$D E_{t} * w_{c t}^{R}$ & $\begin{array}{l}-0.0110 \\
(0.0440)\end{array}$ & $\begin{array}{l}-0.0124 \\
(0.0442)\end{array}$ & $\begin{array}{c}0.0066 \\
(0.0157)\end{array}$ & $\begin{array}{c}0.0075 \\
(0.0158)\end{array}$ \\
\hline$w_{c t}^{I}$ & $\begin{array}{c}-0.2520^{* *} \\
(0.1234)\end{array}$ & $\begin{array}{c}-0.2545^{* *} \\
(0.1214)\end{array}$ & $\begin{array}{c}-0.0997^{* *} \\
(0.0463)\end{array}$ & $\begin{array}{c}-0.1019^{* *} \\
(0.0469)\end{array}$ \\
\hline$D E_{t} * w_{c t}^{I}$ & $\begin{array}{c}0.0445 \\
(0.0456)\end{array}$ & $\begin{array}{c}0.0449 \\
(0.0460)\end{array}$ & $\begin{array}{c}0.0094 \\
(0.0175)\end{array}$ & $\begin{array}{c}0.0078 \\
(0.0178)\end{array}$ \\
\hline$\tau_{c t}$ & $\begin{array}{c}0.0056 \\
(0.0345)\end{array}$ & $\begin{array}{c}0.0003 \\
(0.0346)\end{array}$ & $\begin{array}{c}0.0022 \\
(0.0146)\end{array}$ & $\begin{array}{c}0.0015 \\
(0.0146)\end{array}$ \\
\hline$D E_{t} * \tau_{c t}$ & $\begin{array}{l}-0.0074 \\
(0.0247)\end{array}$ & $\begin{array}{c}-0.0054 \\
(0.0248)\end{array}$ & $\begin{array}{l}-0.0060 \\
(0.0097)\end{array}$ & $\begin{array}{l}-0.0063 \\
(0.0098)\end{array}$ \\
\hline Foreign Exchange Rate $c t$ & $\begin{array}{c}-0.0043 \\
(0.0096)\end{array}$ & $\begin{array}{l}-0.0045 \\
(0.0097)\end{array}$ & $\begin{array}{c}-0.0032 \\
(0.0041)\end{array}$ & $\begin{array}{l}-0.0034 \\
(0.0041)\end{array}$ \\
\hline Real GDP Growth Rate $c t$ & $\begin{array}{c}0.0002 \\
(0.0003)\end{array}$ & $\begin{array}{c}0.0003 \\
(0.0003)\end{array}$ & $\begin{array}{c}-0.0001 \\
(0.0001)\end{array}$ & $\begin{array}{l}-0.0001 \\
(0.0001)\end{array}$ \\
\hline Year 2008 & $\begin{array}{c}0.0029 \\
(0.0023)\end{array}$ & $\begin{array}{c}0.0029 \\
(0.0023)\end{array}$ & $\begin{array}{c}0.0013 \\
(0.0010)\end{array}$ & $\begin{array}{c}0.0013 \\
(0.0010)\end{array}$ \\
\hline Constant & $\begin{array}{c}-0.0200 \\
(0.0331)\end{array}$ & $\begin{array}{c}-0.0087 \\
(0.0334)\end{array}$ & $\begin{array}{c}0.0303^{* * *} \\
(0.0073)\end{array}$ & $\begin{array}{c}0.0281^{* * *} * \\
(0.0079)\end{array}$ \\
\hline Parent Controls & No & Yes & No & Yes \\
\hline Country and Industry Dummies & Yes & Yes & No & No \\
\hline Affiliate Fixed Effects & No & No & Yes & Yes \\
\hline Tobit or OLS & Tobit & Tobit & OLS & OLS \\
\hline Observations & 19,377 & 19,242 & 19,377 & 19,242 \\
\hline R-squared & & & 0.0094 & 0.0095 \\
\hline
\end{tabular}


Table A1: Number of Foreign Affiliates in Each Country

\begin{tabular}{|c|c|c|c|c|c|c|}
\hline Country & 2007 & 2008 & 2009 & 2010 & 2011 & Total \\
\hline Argentina & 11 & 10 & 14 & 13 & 15 & 63 \\
\hline Australia & 153 & 147 & 168 & 172 & 169 & 809 \\
\hline Austria & 17 & 17 & 18 & 19 & 20 & 91 \\
\hline Belgium & 54 & 58 & 58 & 58 & 53 & 281 \\
\hline Brazil & 97 & 108 & 117 & 120 & 121 & 563 \\
\hline Canada & 97 & 107 & 111 & 100 & 111 & 526 \\
\hline Cayman Islands & 16 & 15 & 10 & 6 & 7 & 54 \\
\hline Chile & 15 & 19 & 20 & 17 & 19 & 90 \\
\hline China & 2481 & 2793 & 2767 & 2852 & 3015 & 13908 \\
\hline Czech Republic & 36 & 34 & 35 & 36 & 32 & 173 \\
\hline Denmark & 9 & 10 & 9 & 10 & 12 & 50 \\
\hline France & 107 & 121 & 119 & 117 & 119 & 583 \\
\hline Germany & 272 & 275 & 272 & 262 & 279 & 1360 \\
\hline Hong Kong SAR, China & 537 & 578 & 560 & 568 & 596 & 2839 \\
\hline Hungary & 17 & 19 & 20 & 17 & 24 & 97 \\
\hline India & 88 & 114 & 126 & 141 & 153 & 622 \\
\hline Indonesia & 310 & 316 & 324 & 321 & 374 & 1645 \\
\hline Ireland & 19 & 17 & 15 & 17 & 10 & 78 \\
\hline Italy & 60 & 51 & 51 & 58 & 57 & 277 \\
\hline Korea, Rep. & 324 & 329 & 319 & 343 & 377 & 1692 \\
\hline Malaysia & 340 & 352 & 346 & 356 & 360 & 1754 \\
\hline Mexico & 79 & 72 & 84 & 76 & 91 & 402 \\
\hline Netherlands & 145 & 138 & 132 & 138 & 162 & 715 \\
\hline New Zealand & 29 & 36 & 32 & 37 & 39 & 173 \\
\hline Panama & 71 & 110 & 99 & 96 & 94 & 470 \\
\hline Philippines & 172 & 192 & 204 & 221 & 217 & 1006 \\
\hline Poland & 26 & 29 & 30 & 26 & 29 & 140 \\
\hline Portugal & 12 & 12 & 9 & 12 & 10 & 55 \\
\hline Russian Federation & 17 & 23 & 22 & 28 & 24 & 114 \\
\hline Singapore & 477 & 487 & 452 & 469 & 510 & 2395 \\
\hline South Africa & 13 & 14 & 18 & 19 & 25 & 89 \\
\hline Spain & 54 & 54 & 53 & 54 & 52 & 267 \\
\hline Sweden & 23 & 22 & 23 & 24 & 24 & 116 \\
\hline Switzerland & 23 & 20 & 20 & 14 & 21 & 98 \\
\hline Taiwan & 450 & 474 & 454 & 471 & 497 & 2346 \\
\hline Thailand & 795 & 855 & 850 & 863 & 903 & 4266 \\
\hline Turkey & 13 & 8 & 9 & 10 & 11 & 51 \\
\hline United Arab Emirates & 18 & 23 & 25 & 25 & 27 & 118 \\
\hline United Kingdom & 278 & 279 & 279 & 274 & 282 & 1392 \\
\hline United States & 1350 & 1473 & 1397 & 1389 & 1486 & 7095 \\
\hline Vietnam & 165 & 193 & 209 & 197 & 221 & 985 \\
\hline
\end{tabular}


Table A2: Total Amount of Dividends Paid by Foreign Affiliates in Each Country (in million yen)

\begin{tabular}{|c|c|c|c|c|c|c|}
\hline Country & 2007 & 2008 & 2009 & 2010 & 2011 & Total \\
\hline Argentina & 254 & 537 & 111 & 263 & 178 & 1343 \\
\hline Australia & 38244 & 22975 & 41609 & 72241 & 75737 & 250806 \\
\hline Austria & 254 & 198 & 820 & 818 & 286 & 2376 \\
\hline Belgium & 8776 & 4599 & 18376 & 13545 & 15229 & 60525 \\
\hline Brazil & 35218 & 43693 & 19733 & 16239 & 28952 & 143835 \\
\hline Canada & 18852 & 14856 & 4591 & 8016 & 7775 & 54090 \\
\hline Cayman Islands & 518 & 1199 & 291 & 1075 & 1919 & 5002 \\
\hline Chile & 4260 & 2621 & 3684 & 1227 & 1841 & 13633 \\
\hline China & 248459 & 211405 & 385069 & 199826 & 226115 & 1270874 \\
\hline Czech Republic & 350 & 1482 & 856 & 1318 & 1150 & 5156 \\
\hline Denmark & 190 & 151 & 78 & 19 & 34 & 472 \\
\hline France & 5066 & 6766 & 5565 & 2765 & 6673 & 26835 \\
\hline Germany & 34338 & 27969 & 19091 & 19166 & 15994 & 116558 \\
\hline Hong Kong SAR, China & 46324 & 70797 & 44868 & 50724 & 55562 & 268275 \\
\hline Hungary & 577 & 897 & 10 & 94 & 1287 & 2865 \\
\hline India & 17593 & 16755 & 52336 & 4536 & 4531 & 95751 \\
\hline Indonesia & 24676 & 40795 & 80289 & 19855 & 65098 & 230713 \\
\hline Ireland & 616 & 488 & 403 & 390 & 336 & 2233 \\
\hline Italy & 2536 & 1844 & 6034 & 3870 & 6314 & 20598 \\
\hline Korea, Rep. & 26135 & 21806 & 19930 & 32626 & 27684 & 128181 \\
\hline Malaysia & 21628 & 21223 & 25392 & 17592 & 23080 & 108915 \\
\hline Mexico & 7807 & 8199 & 3816 & 4295 & 5994 & 30111 \\
\hline Netherlands & 39743 & 61971 & 13088 & 27433 & 64468 & 206703 \\
\hline New Zealand & 1792 & 1361 & 1030 & 1070 & 509 & 5762 \\
\hline Panama & 586 & 675 & 1014 & 3165 & 2356 & 7796 \\
\hline Philippines & 14504 & 6980 & 7561 & 12972 & 20492 & 62509 \\
\hline Poland & 5988 & 9507 & 1370 & 1473 & 1355 & 19693 \\
\hline Portugal & 206 & 98 & 138 & 442 & 293 & 1177 \\
\hline Russian Federation & 3160 & 1355 & 119 & 106 & 174 & 4914 \\
\hline Singapore & 78733 & 64094 & 33862 & 78670 & 92116 & 347475 \\
\hline South Africa & 1970 & 1287 & 1054 & 1138 & 1441 & 6890 \\
\hline Spain & 3054 & 1272 & 2467 & 561 & 7931 & 15285 \\
\hline Sweden & 443 & 855 & 293 & 1815 & 258 & 3664 \\
\hline Switzerland & 172 & 504 & 87 & 13 & 697 & 1473 \\
\hline Taiwan & 49086 & 48256 & 34007 & 27483 & 35684 & 194516 \\
\hline Thailand & 119165 & 121239 & 228040 & 148002 & 138639 & 755085 \\
\hline Turkey & 939 & 405 & 6082 & 383 & 392 & 8201 \\
\hline United Arab Emirates & 2765 & 1710 & 2890 & 2138 & 2104 & 11607 \\
\hline United Kingdom & 21514 & 40955 & 29258 & 12516 & 18058 & 122301 \\
\hline United States & 296499 & 106868 & 333878 & 175940 & 490869 & 1404054 \\
\hline Vietnam & 12064 & 15290 & 12410 & 6143 & 9709 & 55616 \\
\hline
\end{tabular}


Table A3: Mean of Affiliate Average Tax Rates in Each Country

\begin{tabular}{|c|c|c|c|c|c|}
\hline Country & 2007 & 2008 & 2009 & 2010 & 2011 \\
\hline Argentina & 0.292 & 0.294 & 0.314 & 0.210 & 0.256 \\
\hline Australia & 0.212 & 0.196 & 0.216 & 0.206 & 0.269 \\
\hline Austria & 0.110 & 0.104 & 0.135 & 0.229 & 0.168 \\
\hline Belgium & 0.233 & 0.215 & 0.174 & 0.184 & 0.224 \\
\hline Brazil & 0.273 & 0.290 & 0.244 & 0.256 & 0.289 \\
\hline Canada & 0.256 & 0.231 & 0.223 & 0.239 & 0.238 \\
\hline Cayman Islands & 0.000 & 0.014 & 0.000 & 0.000 & 0.150 \\
\hline Chile & 0.095 & 0.109 & 0.165 & 0.117 & 0.159 \\
\hline China & 0.094 & 0.102 & 0.105 & 0.153 & 0.177 \\
\hline Czech Republic & 0.106 & 0.123 & 0.080 & 0.097 & 0.127 \\
\hline Denmark & 0.186 & 0.180 & 0.140 & 0.118 & 0.184 \\
\hline France & 0.242 & 0.263 & 0.222 & 0.219 & 0.256 \\
\hline Germany & 0.290 & 0.248 & 0.231 & 0.246 & 0.239 \\
\hline Hong Kong SAR, China & 0.123 & 0.107 & 0.090 & 0.119 & 0.132 \\
\hline Hungary & 0.130 & 0.128 & 0.165 & 0.218 & 0.095 \\
\hline India & 0.278 & 0.260 & 0.212 & 0.239 & 0.206 \\
\hline Indonesia & 0.323 & 0.294 & 0.273 & 0.263 & 0.261 \\
\hline Ireland & 0.088 & 0.078 & 0.049 & 0.068 & 0.116 \\
\hline Italy & 0.518 & 0.393 & 0.373 & 0.400 & 0.453 \\
\hline Korea, Rep. & 0.189 & 0.167 & 0.136 & 0.158 & 0.177 \\
\hline Malaysia & 0.196 & 0.184 & 0.161 & 0.175 & 0.179 \\
\hline Mexico & 0.263 & 0.203 & 0.261 & 0.298 & 0.330 \\
\hline Netherlands & 0.208 & 0.174 & 0.163 & 0.152 & 0.152 \\
\hline New Zealand & 0.257 & 0.192 & 0.241 & 0.404 & 0.196 \\
\hline Panama & 0.009 & 0.007 & 0.002 & 0.022 & 0.007 \\
\hline Philippines & 0.230 & 0.224 & 0.196 & 0.211 & 0.227 \\
\hline Poland & 0.147 & 0.137 & 0.119 & 0.192 & 0.245 \\
\hline Portugal & 0.163 & 0.151 & 0.381 & 0.340 & 0.355 \\
\hline Russian Federation & 0.268 & 0.176 & 0.316 & 0.226 & 0.290 \\
\hline Singapore & 0.143 & 0.154 & 0.124 & 0.136 & 0.112 \\
\hline South Africa & 0.261 & 0.206 & 0.200 & 0.272 & 0.245 \\
\hline Spain & 0.242 & 0.159 & 0.196 & 0.184 & 0.202 \\
\hline Sweden & 0.198 & 0.207 & 0.145 & 0.134 & 0.207 \\
\hline Switzerland & 0.129 & 0.112 & 0.124 & 0.183 & 0.173 \\
\hline Taiwan & 0.235 & 0.238 & 0.234 & 0.194 & 0.178 \\
\hline Thailand & 0.180 & 0.167 & 0.153 & 0.192 & 0.205 \\
\hline Turkey & 0.213 & 0.154 & 0.130 & 0.159 & 0.102 \\
\hline United Arab Emirates & 0.000 & 0.016 & 0.003 & 0.000 & 0.001 \\
\hline United Kingdom & 0.212 & 0.193 & 0.198 & 0.212 & 0.205 \\
\hline United States & 0.263 & 0.230 & 0.214 & 0.245 & 0.252 \\
\hline Vietnam & 0.053 & 0.040 & 0.044 & 0.076 & 0.097 \\
\hline
\end{tabular}

Notes: To bound the average affiliate tax rates between 0 and 1 , we dropped observations with negative corporate tax payments and those with non-positive pretax profits but positive tax payments. We also set the average affiliate tax rate equal to 0 if the tax payment is 0 and the pretax profit is non-positive to bound the average tax rates from zero. The average affiliate tax rates are also winsorized at the top and bottom $1 \%$ to mitigate the influence of outliers. 